\title{
Chondrogenic Potential of Dental-Derived Mesenchymal Stromal Cells
}

\author{
Naveen Jeyaraman ${ }^{1,2,3} \mathbb{D}$, Gollahalli Shivashankar Prajwal 2,3,4 (D), Madhan Jeyaraman $1,2,5,6, *(\mathbb{D})$, \\ Sathish Muthu 2,5,6,7,*(D) and Manish Khanna 2,8 (D)
}

check for updates

Citation: Jeyaraman, N.; Prajwal, G.S.; Jeyaraman, M.; Muthu, S.; Khanna, M. Chondrogenic Potential of Dental-Derived Mesenchymal Stromal Cells. Osteology 2021, 1, 149-174. https://doi.org/10.3390/ osteology1030016

Academic Editor: Jan Zabrzyński

Received: 23 August 2021

Accepted: 13 September 2021

Published: 15 September 2021

Publisher's Note: MDPI stays neutral with regard to jurisdictional claims in published maps and institutional affiliations.

Copyright: (c) 2021 by the authors. Licensee MDPI, Basel, Switzerland. This article is an open access article distributed under the terms and conditions of the Creative Commons Attribution (CC BY) license (https:/ / creativecommons.org/licenses/by/ $4.0 /)$.
1 Department of Orthopaedics, School of Medical Sciences and Research, Sharda University, Greater Noida 201306, India; naveenjeyaraman@yahoo.com

2 Indian Stem Cell Study Group (ISCSG) Association, Lucknow 226010, India; prajwalgs1894@gmail.com (G.S.P.); manishvenus@rediffmail.com (M.K.)

3 Fellowship in Orthopaedic Rheumatology (FEIORA), Dr. Ram Manohar Lohiya National Law University, Lucknow 226010, India

4 Department of Orthopaedics, JJM Medical College, Davangere 577004, India

5 Department of Biotechnology, School of Engineering and Technology, Sharda University, Greater Noida 201306, India

6 Orthopaedic Research Group, Coimbatore 641001, India

7 Department of Orthopaedics, Government Medical College and Hospital, Dindigul 624001, India

8 Department of Orthopaedics, Prasad Institute of Medical Sciences, Lucknow 226010, India

* Correspondence: madhanjeyaraman@gmail.com (M.J.); drsathishmuthu@gmail.com (S.M.)

Featured Application: As an answer to the ongoing search for the ideal source of Mesenchymal Stromal Cells (MSCs) for cartilage tissue engineering, dental issues offers a variety of MSC source in its vicinity. If its chondrogenic potential is validated in future clinical trials, dental tissues would prove to be worth banking for the array of MSC sources it offers.

Abstract: The field of tissue engineering has revolutionized the world in organ and tissue regeneration. With the robust research among regenerative medicine experts and researchers, the plausibility of regenerating cartilage has come into the limelight. For cartilage tissue engineering, orthopedic surgeons and orthobiologists use the mesenchymal stromal cells (MSCs) of various origins along with the cytokines, growth factors, and scaffolds. The least utilized MSCs are of dental origin, which are the richest sources of stromal and progenitor cells. There is a paradigm shift towards the utilization of dental source MSCs in chondrogenesis and cartilage regeneration. Dental-derived MSCs possess similar phenotypes and genotypes like other sources of MSCs along with specific markers such as dentin matrix acidic phosphoprotein (DMP) -1, dentin sialophosphoprotein (DSPP), alkaline phosphatase (ALP), osteopontin (OPN), bone sialoprotein (BSP), and STRO-1. Concerning chondrogenicity, there is literature with marginal use of dental-derived MSCs. Various studies provide evidence for in-vitro and in-vivo chondrogenesis by dental-derived MSCs. With such evidence, clinical trials must be taken up to support or refute the evidence for regenerating cartilage tissues by dental-derived MSCs. This article highlights the significance of dental-derived MSCs for cartilage tissue regeneration.

Keywords: dental pulp; mesenchymal stromal cell; chondrogenicity

\section{Impact Statement}

Dental tissues are the richest sources of mesenchymal stromal cells, which are not much used in clinical practice. Researchers and regenerative medicine clinicians are more interested in exploring the regenerative potential of dental-derived MSCs, which can be translated from bench to bedside clinical applications. The evidence stated that dentalderived MSCs can be used for cartilage regeneration. To explore the chondrogenicity of dental-derived MSCs, clinical trials have to be taken up to support or refute the evidence for cartilage regeneration. 


\section{Introduction}

Cartilage is an avascular and aneural structure with poorly cellularized connective tissue [1,2]. Cartilage tissue facilitates mechanical load transmission with a low frictional coefficient resulting in cartilage injury that has an inherent limited healing potential [3]. The recent idea of "Orthobiologics" led to the exploration of stem cells and regenerative medicine in treating musculoskeletal disorders [4]. Orthobiologics provide administration of osteoinductive and osteoconductive micromolecules to enhance regeneration of degenerated tissues, tendons, bones, and cartilages [4].

Tissue Engineering (TE) is defined as in-vitro or in-vivo regeneration of tissues for repairing and replacing the diseased tissue or organ to enhance and restore the tissue function and maintain tissue homeostasis and improve the biomechanical strength of the tissues [5-7]. Cartilage tissue engineering provides a new strategy by transplanting chondrogenic cells along with biocompatible 3D scaffolds and micromolecules to produce engineered cartilage tissue $[6,8]$. Chondrogenic cells are derived from mesenchymal stromal cells from various sources, namely, bone marrow [9], adipose tissue [10], placenta [11], amniotic fluid [12], Wharton jelly [13], umbilical cord [14], synovium [15], hair follicles [16], dental pulp [17], and gingiva [18]. The tissue engineering triad comprises mesenchymal stromal cells, scaffolds, and biomolecules such as growth factors and cytokines $[8,19]$.

Mesenchymal stromal cells (MSCs) form an integral part of regenerative medicine for cartilage regeneration. MSCs are multipotent stem cells with clonigenicity, plasticity, self-renewal, and differentiation $[20,21]$. MSC differentiate into trilineage namely osteogenesis, chondrogenesis, and adipogenesis [22-24]. Chondrogenesis is mediated by various mediators such as TGF- $\beta 1$ and $-\beta 3$; BMP-2, -4 , and -7; IGF-1; and GDF-5 $[25,26]$. Dental structures provide a variety of stem cells with ease of isolation, non-invasiveness, and availability $[17,27,28]$. Stem cells of dental origin have similar properties of multipotency, diverse differentiative potential, anti-inflammation, immunomodulation, immune privilege like BM-MSCs, AD-MSCs, and Sy-MSCs [29,30]. This article throws light on MSCs of dental origin in chondrogenesis and cartilage regeneration in osteoarthritic knees.

\section{MSCs of Dental Origin}

Stem cells of dental origin form a good therapeutic paradigm in regenerating tissues, bones, and cartilage. MSCs of dental origin include (a) dental pulp MSCs (DP-MSCs) [31,32], (b) stem cells from human exfoliated deciduous teeth (SHEDs) [33,34], (c) periodontal ligament stem cells (PDLSCs) [35,36], (d) dental follicle precursor cells (DFPCs) [37,38], (e) stem cells from apical papilla (SCAPs) [39,40], and (f) gingival derived MSCs (G-MSCs) [41,42]. Among all these sources of dental stem cells, researchers pay attention to DP-MSCs and SHEDs because of ease in their accessibility. The various sources of MSCs of dental origin are shown in Figure 1.

\subsection{Dental Pulp MSCs (DP-MSCs)}

Embryologically, dental pulp arises from ectomesenchyme where the periphery of the neural tube gives rise to ectodermal cells and migrates to the oromaxillary region, and differentiates into mesenchymal phenotype. The dental pulp remains an unmineralized connective tissue that comprises a heterogeneous population including stromal cells, progenitors, odontoblasts, ameloblasts, fibroblasts, granulocytes, macrophages, vascular fragments, capillaries, and extracellular matrices. Dental pulp tissue is the richest source of MSCs, which are extracted from the teeth recovered during routine dental procedures [32]. DP-MSCs are isolated from impacted third molars and supernumerary teeth, which possess extreme clonigenicty, plasticity, regenerative and reparative potential $[43,44]$. These cells reside within the dental crown called "niche" or "pulp chamber" [45]. The usage of DP-MSCs was documented with diabetes mellitus [46], neurological disorders [47], maxillofacial and dental disorders [48], disorders of bone and cartilage [49], hepatic disorders [50], and immunological diseases [51]. The extraction of MSCs from dental structures remains non-invasive and can be cryopreserved for future usage. 


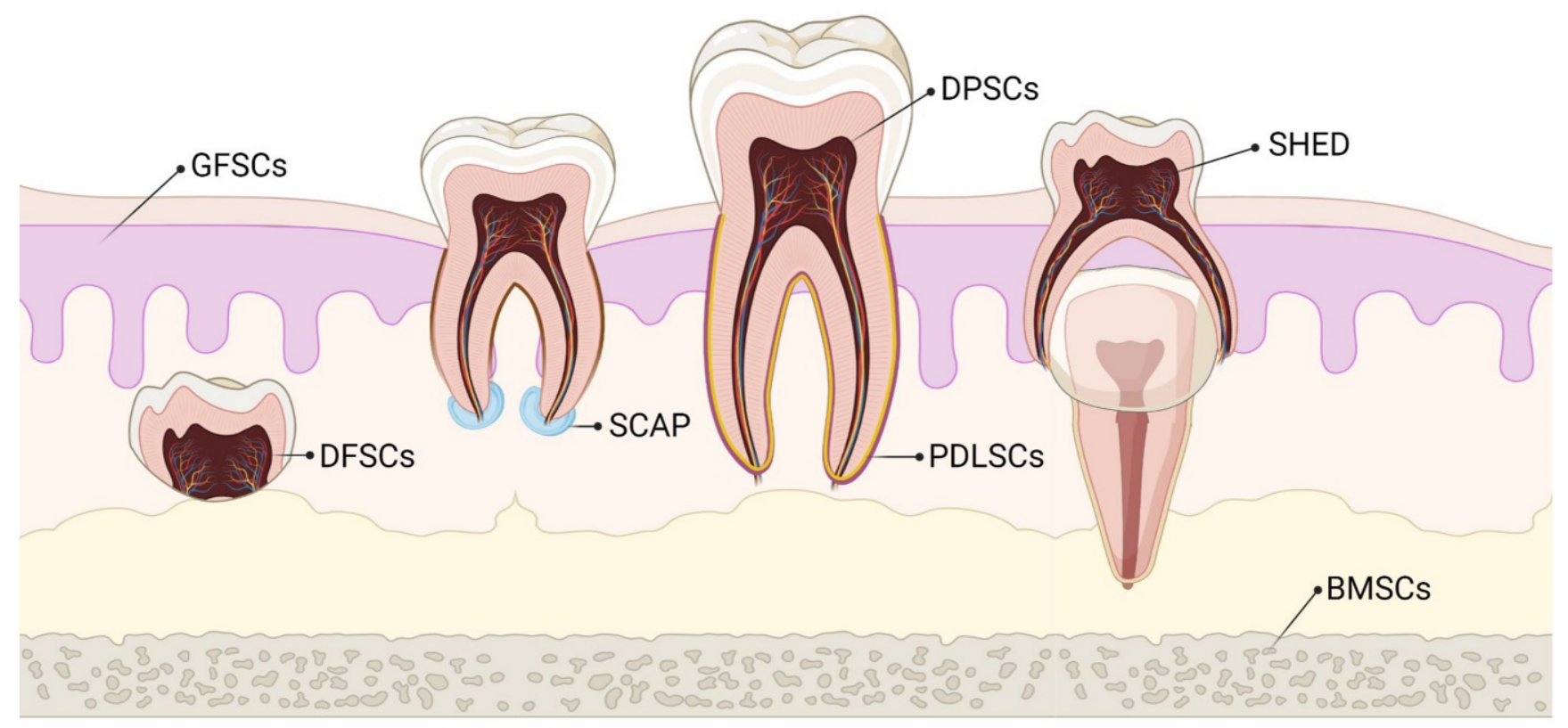

Figure 1. Various sources of stem cells of dental origin. BMSCs-Bone Marrow Stem Cells; DFSCs-Dental Follicle Stem Cells; DPSCs-Dental Pulp Stem Cells; GFSCs-Gingival Fibroblastic Stem Cells; PDLSCs-Periodontal Ligament Stem Cells; SCAP-Stem Cells of Apical Papilla; SHED-Stem cells of Human Exfoliated Deciduous teeth.

During dentinogenesis, the interplay between dental pulp epithelial cells leads to the differentiation of odontoblasts and ameloblasts, which deposit dentin and enamel, respectively. The inner lining of dental pulp contains progenitor cells with high regenerative potential throughout the lifetime [52]. DP-MSCs possess a similar regenerative potential to BM-MSCs, but DP-MSCs act as a non-invasive source for extraction of MSCs for therapeutic usage in various diseases [51,53].

Upon addition of appropriate growth factors, micromolecules, transcriptional factors, and ECM proteins, DP-MSCs differentiate into multilineages, namely, adipogenesis, chondrogenesis, osteogenesis, neurogenesis, and dentinogenesis both in in-vitro and in-vivo studies $[54,55]$. During any insult to dental structures, due to the higher proliferative capacity, the quiescent DP-MSCs activate and immediately differentiate into ameloblasts, odontoblasts, osteoblasts, adipocytes, and chondrocytes to produce dentin, bone, fat, and cartilage for their repair process, respectively $[27,56]$. Yu et al. demonstrated the reduced odontoblastogenesis after the ninth passage and differentiation of osteoblast precursors [57]. Since DP-MSCs are derived from the neural crest, they possess neural crest stem cell markers and hence they differentiate into neuron-like cells [58-60]. Superior chondrogenesis was exhibited by DP-MSCs both in-vitro and in-vivo when compared with BM-MSCs [61-64].

\subsection{Stem Cells from Human Exfoliated Deciduous Teeth (SHEDs)}

SHEDs are stromal cells extracted from exfoliated deciduous teeth, which behave in the line of embryonic stem cells [65]. They possess MSC markers, epidermal stem cell markers, and tumor recognition markers, but do not exhibit hematopoietic stem cell markers [66]. SHEDs demonstrate higher proliferation and differentiation ability and form cell cluster formation like a sphere when compared with DP-MSCs $[67,68]$. They enhance osteogenic differentiation due to the presence of higher levels of osteocalcin, and alkaline phosphatase. SHEDs when mixed with platelet-rich plasma, the osteogenic response accelerated in mandibular defects in canines [69] SHEDs play a major role in treating diabetes mellitus $[70,71]$ and neurological disorders such as spinal cord injury [72], focal cerebral ischemia $[73,74]$, and Alzheimer's disease $[75,76]$. Muhammad et al. observed the upregulation of MMP-13, NF-kB, aggrecan, ECM proteins, and COL-2 in the regenerated chondrocytes with SHEDs, which underscored the basis for OA knee management [77]. 


\subsection{Periodontal Ligament Stem Cells (PDLSCs)}

PDLSCs are situated in the perivascular wall of periodontal ligaments and mimic pericytes with diverse differentiation and regeneration potential and their ability to form capillary-like structures in-vitro [78,79]. On their cell surface, they show pericyte-associated markers CD-146, and -140B and neural/glial antigen-2 [79,80]. PDLSCs are isolated from the mid-third portion of the root surface after permanent tooth extraction and alveolar socket [78]. Wang et al. reported that alveolar socket-derived PDLSCs possess higher proliferative and differentiative potential than root-derived PDLSCs [81]. Silverio et al. emphasized that deciduous teeth-derived PDLSCs (d-PDLSCs) possess greater proliferation, stronger adipogenic, and osteogenic potential than permanent teeth-derived PDLSCs (p-PDLSCs) [82]. PDLSCs possess strong immunomodulatory, anti-fibrotic, and antiinflammatory capacities like BM-MSCs and AD-MSCs $[83,84]$. PDLSCs enhance chondrogenesis by the addition of TGF- $\beta 3$ and BMP- 6 . In tissue analysis, there was increased expression of SOX-9, TGF- $\beta 3$, BMP-6, aggrecan, COL-2, and 10 and Runx 2 in the chondrogenic cells [30].

\subsection{Dental Follicle Precursor Cells (DFPCs)}

The dental follicle (DF) is a loose connective tissue derived from ectomesenchyme that surrounds the tooth germ [85]. Compared to other stem cells of dental origin, DFPCs exhibit robust immunomodulation, proliferative and diverse differentiative potential $[37,86]$. Evidence proved that DFPCs differentiate into the alveolar bone, PDL, cementum, adipocyte, osteoblast, cementoblast/chondrocyte, neuron-like cell cardiomyocyte, and dentin-like tissues $[45,85]$. Researchers have extensively utilized DFPCs for regenerating bone defects, cartilage engineering, tooth root, and periodontal tissue regeneration, and neural tissue regeneration. DFPCs express NOTCH-1 transmembrane protein, which decides the fate of the cell to be differentiated and HLA-ABC, which is acquired during culture [87]. When co-cultured with lymphocytes, DFPCs exhibit decreased INF- $\gamma$ and IL-4 and increased IL- 6 , and -10 and TGF- $\beta$. Transplanted DFPCs regenerate bone in the calvarial defect when loaded with polycaprolactone (PCL) scaffold along with hyaluronate and $\beta$-tricalcium phosphate [88]. Periodontal osteogenesis of DFPCs is enhanced with nanosilicates and fluoride additives [89].

\subsection{Stem Cells from Apical Papilla (SCAPs)}

SCAPs are a novel group of MSCs that reside inside the apical papilla of immature permanent teeth [90]. SCAPs possess superior osteogenic differentiation potential $[90,91]$ and inferior adipogenic differentiation potential than BM-MSCs [91,92]. Inherently, SCAPs contain enormous levels of dentin sialophosphoprotein, bone sialoprotein, alkaline phosphatase, bone $\gamma$-carboxyglutamate protein, BMP-2, -7 and -9 , and Runt-related transcription factor 2 renders them more osteogenic potential [93]. SCAPs exhibit an innate property for neoangiogenesis due to the presence of VEGF, bFGF, MMPs, IGF-BP3, and thrombospondin-1 [94,95]. When induced with platelet lysate or growth factors, SCAPs show a greater proliferation rate $[95,96]$. While compared with DP-MSCs, SCAPs exhibit higher levels of survivin, longer telomere length with higher telomerase activity, increased cellular turnover and proliferation rate $[97,98]$. They secrete significantly higher amounts of chemokines, neurotrophins, transcription proteins, and growth factors than BM-MSCs [99]. With knock-down of LINC01013, SCAPs enhance chondrogenic differentiation and proliferation by the increased expressions of DLX-5, HOXC 8, COL-2 and -5 , and SOX-9 in a pellet culture system $[47,100]$.

\subsection{Gingival-Derived MSCs (G-MSCs)}

Gingiva becomes a more readily available and accessible source of stem or progenitor cells in the oral cavity. G-MSCs are extracted from gingival lamina propria and free or inflamed or hyperplastic gingiva $[101,102]$. When transplanted to the site of action, G-MSCs form connective tissue-like structures along with extracellular matrices than other sources 
of dental stem cells $[57,58]$. This property draws great attention among regenerative specialists to explore more on G-MSCs. G-MSCs are easy to isolate and extract from naïve tissues, uniformly homogeneous, possess stable phenotype, cellular turnover, and proliferation rate, maintain telomerase activity in long-term cultures and higher grade passages [103,104] G-MSCS promotes macrophage polarization to the M2 phenotype and provides an antiinflammatory environment in the wound bed and promotes vasculogenesis and enhances wound repair [105]. Injection of biodegradable TGF- $\beta 3$-loaded hydrogel microspheres along with clinical-grade G-MSCs enhance tendon regeneration in an immunocompromised mouse [106]. Wang et al. demonstrated bone regeneration in mandibular and calvarial defects in rats within two months of transplantation of G-MSCs [107].

\section{Characterization of Dental-Derived MSCs (D-MSCs)}

DP-MSCs and SHEDs possess similar immunophenotype like BM-MSCs, AD-MSCs, and SyMSCs [108-110]. DP-MSCs and SHEDs possess cell markers of MSCs (CD-13 [alanyl aminopeptidase], -44, -73 [ecto-5'-nucleotidase], -90, -105 [endoglin], -146, and -166, STRO-1) [111], osteogenic markers (BMP-2, OCN, OPN, osteonectin, and COL-1) [112], adipogenic markers (LPL and PPAR- $\gamma$ ) [113], chondrogenic markers (SOX-9 and COL-2) [110,112], myogenic markers (myosin, myogenin, and SMA- $\alpha$ ) [114], neurogenic markers (nestin, GFAP, MAP-2, and $\beta 3$ tubulin) [115-117], and pluripotency markers (OCT-4, SOX-2, Nanog, and IGF-1R) [118,119]. They demonstrate negative staining for hematopoietic markers (CD-14, $-19,-34,-45$, and HLA-DR) $[109,120]$.

The specific markers for D-MSCs are markers of odontoblast differentiation [dental matrix protein-1 (DMP-1) and dentine sialophosphoprotein (DSPP)] [121], markers of extracellular matrix [alkaline phosphatase (ALP)] [122], makers of osteogenic differentiation [osteopontin (OPN)] [123], markers of mineralized tissue differentiation [bone sialoprotein (BSP)] [124], and markers of differentiating potential of D-MSCs [STRO-1] [125].

Biodentine, a bioactive dentine substitute, is capable of inducing DP-MSCs differentiation of odontoblasts. Luo et al. demonstrated odontoblast differentiation of DP-MSCs by increased expression of ALP, OCN, DSPP, DMP1, and BSP [126]. Optimal mechanical compression increased the expression of DSPP, BMP-7, and Wnt10a genes for odontoblast differentiation by DP-MSCs [127]. BBX gene expression induces the differentiation of odontoblasts by DP-MSCs [128]. DNA methylation and PTEN expression were increased in DP-MSCs, which are responsible for lineage differentiation and reduced oncogenesis when compared with BM-MSCs [129]. The differential characteristics of individual MSCs of dental origin are given in Table 1. 


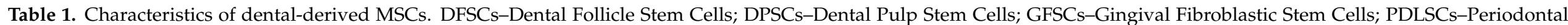

Ligament Stem Cells; SCAP-Stem Cells of Apical Papilla; SHED-Stem cells of Human Exfoliated Deciduous teeth (++ low; +++ medium; ++++ high; $\uparrow$ increased; $\downarrow$ decreased).

\begin{tabular}{|c|c|c|c|c|c|c|}
\hline \multirow{2}{*}{$\begin{array}{c}\text { Type of Dental-Derived } \\
\text { MSCs }\end{array}$} & \multicolumn{2}{|c|}{ CD Markers } & \multirow{2}{*}{$\begin{array}{l}\text { Proliferative } \\
\text { Potential }\end{array}$} & \multirow{2}{*}{ Differentiative Potential } & \multirow{2}{*}{$\begin{array}{c}\text { Immunomodulatory } \\
\text { Capacity }\end{array}$} & \multirow{2}{*}{ Clinical Application } \\
\hline & Positive & Negative & & & & \\
\hline DP-MSCs & $\begin{array}{c}\text { CD-9, }-10,-13,-29,-44, \\
-59,-73,-90,-105,-146, \\
-106,-146,-166,-271, \\
\text { STRO-1, TRA1-60, } \\
\text { NANOG, SOX-2, Oct-4, } \\
\text { and TRA-1-80-1 }\end{array}$ & $\begin{array}{c}\text { CD-14, }-19,-24,-117,-34 \\
-45,-31, \text { and }-133\end{array}$ & +++ & $\begin{array}{l}\text { Adipocyte, dentin-pulp, } \\
\text { bone muscle/odontoblast, } \\
\text { myoblast adipocyte, } \\
\text { osteoblast, neuron-like cell, } \\
\text { cardiomyocyte, and } \\
\text { hepatocyte-like cell }\end{array}$ & $\begin{array}{c}\uparrow \text { HGF, TGF } \beta, \text { PGE-2, IL-6, } \\
\text { IDO, and IL-10 } \\
\downarrow \text { IL-4 and IFN- } \gamma ; \\
\uparrow \text { number of Tregs; } \\
\downarrow \text { proliferation of T cells and } \\
\text { PBMCs; } \\
\text { Inducing activated T cells } \\
\text { apoptosis }\end{array}$ & $\begin{array}{l}\text { Bone defects, dentin } \\
\text { pulp repair, neural tissue } \\
\text { regeneration, diabetes } \\
\text { mellitus, immunological } \\
\text { disorders, and } \\
\text { chondrogenesis }\end{array}$ \\
\hline SHED & $\begin{array}{l}\text { CD-29, -73, -90, -105, } \\
\text {-146, -166, STRO-1, } \\
\text { NANOG, and nestin }\end{array}$ & CD-14, -34 , and -45 & ++ & $\begin{array}{l}\text { Bone dentin-pulp, mi- } \\
\text { crovessels/chondrocyte, } \\
\text { myocytes, adipocytes, } \\
\text { osteoblasts, and } \\
\text { neuron-like cell }\end{array}$ & $\begin{array}{c}\text { Inhibited Th17 cell } \\
\text { differentiation; } \\
\uparrow \text { number of Tregs; } \\
\text { Corrected CD4+ T cell } \\
\text { immune imbalance in } \\
\text { allergic diseases; } \\
\uparrow \text { IL-10 and } \downarrow \text { IL- } 4 \text { and IFN- } \gamma\end{array}$ & $\begin{array}{l}\text { Craniofacial bone } \\
\text { defects, dentin-pulp } \\
\text { repair, neural } \\
\text { regeneration, tooth root } \\
\text { regeneration, diabetes } \\
\text { mellitus, spinal cord } \\
\text { injury, focal cerebral } \\
\text { ischemia, and } \\
\text { Alzheimer's disease }\end{array}$ \\
\hline PDLSCs & $\begin{array}{c}\text { CD-9, }-10,-13,-29,-44 \\
-59,-73,-90,-105,-106, \\
-146,-166,-271, \text { and } \\
\text { STRO-1 }\end{array}$ & $\begin{array}{l}\text { CD-11b, -14, -19, -34, -45, } \\
-79 \alpha, \text { and HLA-DR }\end{array}$ & ++ & $\begin{array}{c}\text { Cementum, } \\
\text { PDL/chondrocyte, } \\
\text { osteoblast, cementoblast, } \\
\text { adipocyte, and } \\
\text { neuron-like cell }\end{array}$ & $\begin{array}{c}\uparrow \text { expression of TLR-2 and }-4 ; \\
\uparrow \text { release IDO, HGF, } \\
\text { and TGF } \beta ; \\
\downarrow \text { proliferation of PBMCs } \\
\text { and reduced induction } \\
\text { of Tregs }\end{array}$ & $\begin{array}{l}\text { Tooth root and } \\
\text { periodontal tissue } \\
\text { regeneration }\end{array}$ \\
\hline DFSCs & $\begin{array}{c}\text { CD-9, -10, -13, -29, -44, } \\
-53,-56,-59,-73,-90,-105, \\
-106,-146,-166,-271, \\
\text { STRO-1, NOTCH-1, } \\
\text { HLA-ABC, NANOG, } \\
\text { SOX-2, OCT-4, nestin, } \\
\text { and } \beta 3-\text { tubulin }\end{array}$ & CD-31, $-34,-45$, and -133 & ++++ & $\begin{array}{l}\text { Alveolar bone, PDL, } \\
\text { cementum, adipocyte, } \\
\text { osteoblast, cemento- } \\
\text { blast/chondrocyte, } \\
\text { neuron-like cell } \\
\text { cardiomyocyte, and } \\
\text { dentin-like tissue }\end{array}$ & $\begin{array}{c}\uparrow \text { expression of TLR-2, }-3 \text {, } \\
\text { and -4; } \\
\uparrow \text { IL-10, IL-6, TGF } \beta \text {, and } \\
\text { IDO-1; } \\
\downarrow \text { IFN- } \gamma, \text { IL-4, and IL-8; } \\
\downarrow \text { proliferation of PBMCs; } \\
\downarrow \text { number of CD4+ T cells } \\
\text { and } \uparrow \text { Tregs }\end{array}$ & $\begin{array}{l}\text { Bone defects, cartilage } \\
\text { engineering, tooth root, } \\
\text { and periodontal tissue } \\
\text { regeneration, and neural } \\
\text { tissue regeneration }\end{array}$ \\
\hline
\end{tabular}


Table 1. Cont.

\begin{tabular}{|c|c|c|c|c|c|c|}
\hline \multirow{2}{*}{$\begin{array}{c}\text { Type of Dental-Derived } \\
\text { MSCs }\end{array}$} & \multicolumn{2}{|c|}{ CD Markers } & \multirow{2}{*}{$\begin{array}{l}\text { Proliferative } \\
\text { Potential }\end{array}$} & \multirow{2}{*}{ Differentiative Potential } & \multirow{2}{*}{$\begin{array}{c}\text { Immunomodulatory } \\
\text { Capacity }\end{array}$} & \multirow{2}{*}{ Clinical Application } \\
\hline & Positive & Negative & & & & \\
\hline SCAP & $\begin{array}{l}\text { CD-13, -29, }-49,-51,-56, \\
-61,-73,-146,-90,-44,-24, \\
-106,-146,-166, \text { STRO-1, } \\
\text { NANOG, and nestin }\end{array}$ & CD-14, $-18,-34$, and -45 & ++ & $\begin{array}{l}\text { Dentin-pulp/osteoblast, } \\
\text { adipocyte, odontoblasts, } \\
\text { hepatocytes, and } \\
\text { neuron-like cell }\end{array}$ & $\begin{array}{c}\text { Inhibited proliferation of T } \\
\text { cells; } \\
\text { Overexpressed Nfic to } \\
\text { suppress LPS-initiated } \\
\text { innate immune responses }\end{array}$ & $\begin{array}{l}\text { Bone regeneration, tooth } \\
\text { root regeneration, } \\
\text { dentin-pulp repair, } \\
\text { neural regeneration }\end{array}$ \\
\hline GFSCs & $\begin{array}{c}\text { CD-29, }-44,-73,-90,-105 \\
-106,-166, \text { STRO-1, } \\
\text { NANOG, and nestin }\end{array}$ & CD-14, $-117,-34$, and -45 & ++ & $\begin{array}{l}\text { Cartilage, bone, } \\
\text { muscle/adipocyte, } \\
\text { chondrocyte, osteocyte, } \\
\text { and neuron-like cell }\end{array}$ & $\begin{array}{c}\uparrow \text { expression of TLR-1, }-4,-5 \text {, } \\
-7 \text {, and }-10 ; \\
\text { Inhibited proliferation of T } \\
\text { cells and Th17; } \\
\uparrow \text { CD4+ CD25+ FoxP3+ } \\
\text { Tregs; releasing IL-6, IDO, } \\
\text { IL-10, COX-2, and iNOS }\end{array}$ & $\begin{array}{l}\text { Calvarial defects, neural } \\
\text { regeneration, and } \\
\text { periodontal regeneration }\end{array}$ \\
\hline
\end{tabular}




\section{Harvesting and Delivery Methods of D-MSCs}

Various regenerative medicine experts followed different methods to extract and harvest stromal cells from dental pulp.

Raoof et al. used three different methods to isolate DP-MSCs, namely, (a) digestion of dental pulp tissue with collagenase and placement of isolated trypsinized cells in petri dishes, (b) explantation of undigested dental pulp pieces to culture plates, and (c) explantation of trypsinized dental pulp tissues to petri dishes for outgrowth [130]. These tissues are plated to MEM medium supplemented with $20 \%$ fetal bovine serum at $37^{\circ} \mathrm{C}$ with a $5 \% \mathrm{CO}_{2}$ incubator. A total of $60 \%$ cellular confluency was achieved within days of culture and checked for pluripotency markers by RT/PCR analysis [130].

Naz et al. expanded DP-MSCs and SHEDs via the explant culture method after extirpation of dental pulp tissues from deciduous teeth [131]. As a result of culture expansion, MSCs exhibit fibroblast-like cells with long cytoplasmic processes. DP-MSCs and SHEDs characterization was done and cryopreserved for future use as shown in Figure 2.
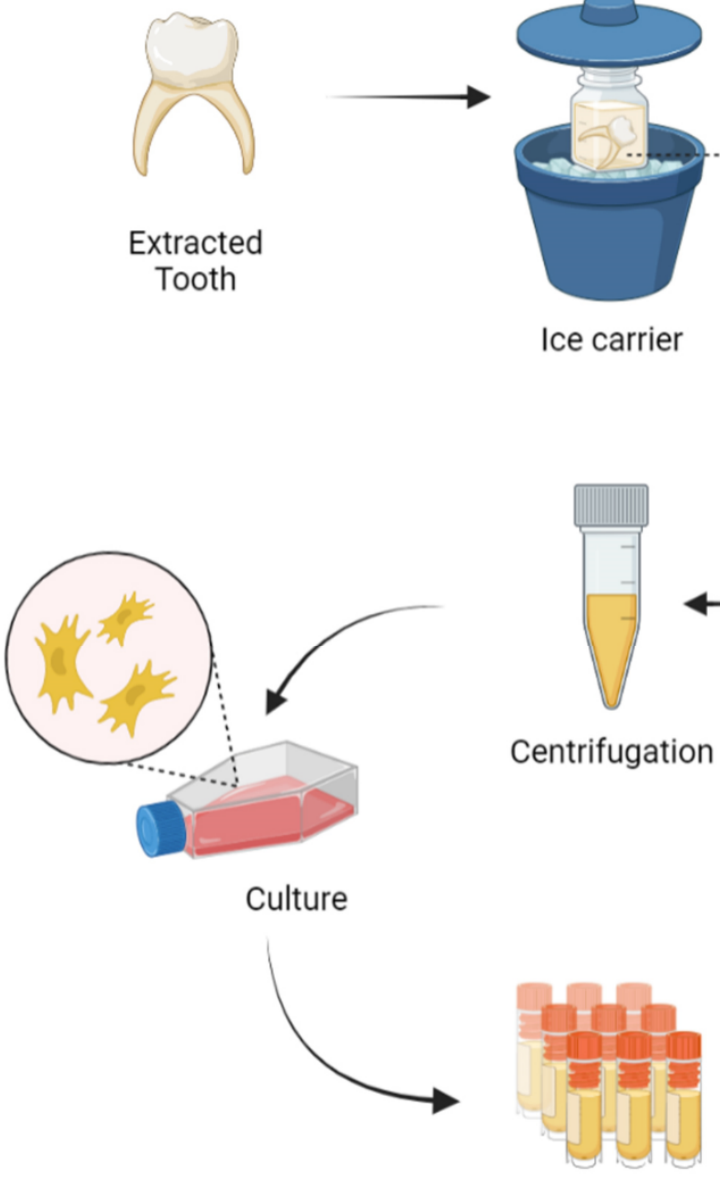

Culture

Expansion

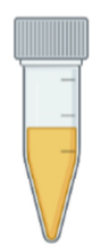

Centrifugation
Ice carrier

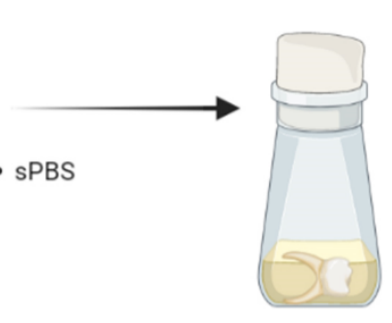

Disinfection

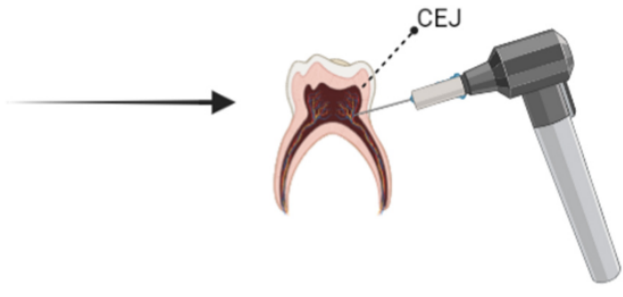

Decoronation
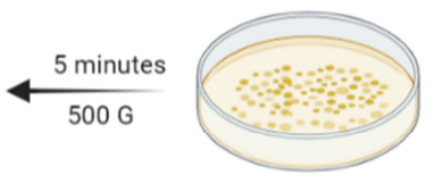

Dental Pulp tissue
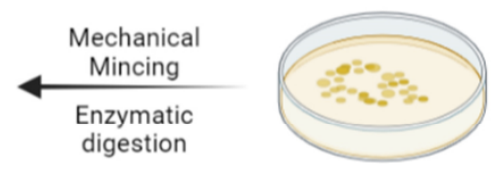

Dental Pulp fragments

Figure 2. Harvesting and delivery method of DP-MSCs. sPBS—sterile phosphate buffer saline; CEJ—cementum enamel junction.

No significant change was observed in the differentiating capabilities and immunophenotypic properties of cryopreserved and non-cryopreserved DP-MSCs isolated from dental pulp, but there were significant differences in the morphology and proliferative potential of cryopreserved DP-MSCs than non-cryopreserved DP-MSCs [132].

The survival rates of DP-MSCs in DMSO free medium by static magnetic cryopreservation increased by 2 to 2.5 fold when the cells were exposed to 0.4 or 0.8 -T static magnetic 
fields [133]. Gioventù et al. demonstrated that cryopreserved teeth by laser piercing have maintained cellular viability [134].

To isolate a pure population of DP-MSCs, the identification of cell surface markers like LNGFR and THY-1 are significant $[87,88]$. The assessment of the number of colonies showed that LNGFR ${ }^{\text {Low+ }}$ THY- $1^{\text {High+ }}$ cells in the dental pulp have a significantly higher colony-forming potential than $\mathrm{LNGFR}^{+} \mathrm{THY}-1^{+}$cells in the bone marrow [135-137].

\section{Chondrogenicity of Dental-Derived MSCs}

Though dental-derived stem cells possess higher osteogenic potential, they are being explored very marginally for chondrogenicity. DP-MSCs act as a promising source for cartilage tissue engineering and regeneration. DP-MSCs possess a strong potential to differentiate into hyaline and fibrocartilage [138]. Sophia et al. demonstrated that hyaline cartilage contains few chondrocytes in their extracellular matrix rich in GAGs and type 2 collagen [2], whereas Allen et al. stated that fibrocartilage contains fibroblastic cells with small amounts of GAGs and type 1 collagen [139].

Longoni et al. expanded DP-MSCs from seven molar teeth and induced chondrogenesis in a 3D pellet culture system [63]. These culture-expanded DP-MSCs display GAGs, aggrecan, and type 2 collagen after three weeks. The assessment of culture-expanded cells revealed fibroblastic cells with long cytoplasmic processes with a predominance of type 1 collagen to state the formation of fibrocartilage. They concluded that DP-MSCs regenerate fibrocartilage in joints, rather than hyaline cartilage.

DP-MSCs provide a rapid ex-vivo expansion and chondrogenic differentiation potential and hence provide a favorable cell type for treating cartilage disorders. Khajeh et al. demonstrated a significant role of hypoxia mimicking agent and cobalt chloride on chondrogenesis with DP-MSCs [140]. Cobalt chloride exposure to DP-MSCs increases the cellular pellet mass in culture, cellular morphology and integrity, ECM deposition, and cellular organizations. There were elevated levels of GAGs and type 2 collagen expression [141]. Cobalt chloride enhances the stemness of DP-MSCs where flow cytometry reveals the increased expression of STRO- $1^{+}$cells [142].

SHEDs lose stemness and compromise the therapeutic effects when cultured and expanded in vitro for the long term. Hypoxia is a major factor in the maintenance of stemness of MSCs $[143,144]$. SHEDs, when co-cultured with cobalt chloride, increased the hypoxia-inducible factor- $1 \alpha$ in a dose-dependent manner, resulted in increased expression of STRO- $1^{+}$cells and stem/stromal cell markers such as OCT4, NANOG, SOX2, and c-Myc and decreased osteogenic differentiation by reducing ALP levels [141]. Hypoxia suppresses chondrogenic hypertrophy in agarose or alginate-chondroitin sulfate-platelet lysate hydrogel and 3D pellet culture system in cartilage tissue engineering $[145,146]$. At the protein level, the inhibitors of chondrocyte hypertrophy are PTHrP, TGF- $\beta 3$, BMP- $4,-7$, and -13, GG86/2, Dorsomorphin, and FK506, whereas, at the gene level, Nkx3.2, SOX-9, Smad6, HDAC4, ChM1, sFlt-1, and C-1-1 are responsible for inhibiting chondrocyte hypertrophy during culture [147-151]. The chondrogenesis due to hypoxia is mediated through SOX-9 gene transcription or p38 MAPK gene activation [152]. Hypoxia promotes chondrogenic differentiation and cartilage extracellular matrix synthesis and suppresses terminal chondrocyte differentiation and hence the hypoxia phenomenon preserves chondrocyte phenotype and function during chondrogenesis [153].

Hsu et al. cultured human gingival fibroblast (HGF) cells on chitosan membrane to observe in-vitro chondrogenesis. On culture, increased spheroid formation resulted, which indicates the stemness of HGF. Spheroid formation by HGF was supported by Rho/Rho-associated kinases and the connexion 43 pathway. Hence, they concluded that culturing HGF on chitosan membrane induces spheroid formation, which further induces chondrogenesis by the ROCK pathway [154].

Ferre et al. demonstrated osteogenesis and chondrogenesis by human gingival stem cells in vitro in 3D floating micromass pellet cultures in a specified medium. Osteogenic cells exhibited the increased expression of Runx-2, ALP, presence of osteoid-like mass, and 
osterix expression whereas chondrogenic cells exhibited increased expression of type 2 collagen, GAGs, and SOX-9 transcription gene [155].

SOX-9, the master gene for chondrogenesis, helps in the proliferation of chondrocytes, but not in chondrocyte hypertrophy [156]. SOX-9 gene was expressed in human gingival stem cells at the basal level without chondrogenic stimulation [157]. Such basal expression of SOX-9 explains efficient chondrogenesis. SOX-9 gene knock-out mice were unable to regenerate normal cartilage despite MSC condensation [158-161]. The chondrogenesis by SOX-9 is due to

(1) chondrocyte expression of SOX-9 until growth plate hypertrophy and in articular cartilage throughout life in adults,

(2) to secure lineage specificity towards chondrogenesis in fetal and postnatal growth plates,

(3) to maintain adult cartilage homeostasis,

(4) and to repress non-chondrogenic lineages in gene level [115-117].

Ferre et al. demonstrated the differentiation of type 10 collagen secreting hypertrophic chondrocytes and fibroblast-like synoviocytes by human gingival stem cells. Under hypoxia and hypoxic mimicking environment, G-MSCs express high levels of VEGF- $\alpha$, which promote vasculogenesis for regenerative therapies [155].

$\mathrm{NOTCH}$ ligand signaling plays a major role in the chondrogenic differentiation of cells [162]. NOTCH-2 modulates the activities of NOTCH-3 and -1, hence influence the growth and development, and homeostasis of chondrocytes and articular cartilage [163-165]. NOTCH-3 represses the proliferation of terminally differentiated chondrocytes within the cartilaginous tissues [166]. In a 3D-cultured chondrogenesis, there is a downregulation of NOTCH ligands and receptors $[167,168]$. While MSC undergoes terminal chondrocyte differentiation, NOTCH-3 receptors were upregulated and were highly expressed [162,169]. Various studies on the in vitro and in vivo chondrogenic potential of MSCs of dental origin are given in Tables 2 and 3, respectively. 
Table 2. In-vitro chondrogenicity of MSCs of dental origin.

\begin{tabular}{|c|c|c|c|c|c|c|c|}
\hline Author & Objectives & Type of Scaffold & $\begin{array}{l}\text { Chondrogenic } \\
\text { Differentiation }\end{array}$ & Time Evaluation & Cell Passage & Growth Factor & Results \\
\hline $\begin{array}{l}\text { Fernandes et al. [170]. } \\
\qquad(2018)\end{array}$ & $\begin{array}{c}\text { Animal model for DP- } \\
\text { MSCs for } \\
\text { cartilage } \\
\text { regeneration }\end{array}$ & Collage n type I/III & No & 6 weeks & $\begin{array}{c}\text { Not } \\
\text { described }\end{array}$ & No & $\begin{array}{l}\text { Able to differnetiate into } \\
\text { bone and cartilage in-vitro }\end{array}$ \\
\hline $\begin{array}{l}\text { Westin et al. [171]. } \\
\qquad(2017)\end{array}$ & $\begin{array}{l}\text { Analyze the culture } \\
\text { and differentiation of } \\
\text { DP-MSCs into } \\
\text { chondrocytes using } \\
\text { scaffolds }\end{array}$ & $\begin{array}{l}\text { Chitosa n-xanthan } \\
\text { gum matrice s }\end{array}$ & $\begin{array}{l}\text { DMEM } \\
\text { supplemented with } \\
\text { ascorbate, proline, } \\
\text { ITS, dexamethasone, } \\
\text { kartogenin }\end{array}$ & $\begin{array}{l}24 \mathrm{~h} \text { and } 14 \text { days } \\
\text { after cells seeding }\end{array}$ & No & No & $\begin{array}{l}\text { DP-MSCs seeded along } \\
\text { with scaffolds } \\
\text { differentiate into } \\
\text { chondrocytes when } \\
\text { cultured in chondrogenic } \\
\text { medium containing } \\
\text { kartogenin for } 14 \text { days }\end{array}$ \\
\hline $\begin{array}{l}\text { Mata et al. [172]. } \\
\text { (2017) }\end{array}$ & $\begin{array}{l}\text { Chondrogenic ability } \\
\text { of hDP-MSCs to } \\
\text { regenerate cartilage } \\
\text { in vitro and in vivo }\end{array}$ & $\begin{array}{c}3 \% \\
\text { alginate scaffold }\end{array}$ & $\begin{array}{l}\text { DMEM with } 1 \% \\
\text { insulin-transferrin- } \\
\text { sodium selenite } \\
\text { medium supplement } \\
\text { and ascorbate }\end{array}$ & 3 months & $\begin{array}{c}\text { Not } \\
\text { described }\end{array}$ & No & $\begin{array}{l}\text { By end of } 3 \text { months, a } \\
\text { significant cartilage } \\
\text { regeneration observed in } \\
\text { rabbit model }\end{array}$ \\
\hline $\begin{array}{l}\text { Chen et al. [174]. } \\
\text { (2014) }\end{array}$ & $\begin{array}{l}\text { Chondrogenic } \\
\text { potential of SHED with } \\
\text { TCP scaffold in vitro } \\
\text { and in vivo }\end{array}$ & $\begin{array}{l}\beta \text {-tricalcium } \\
\text { phosphate }\end{array}$ & $\begin{array}{c}\text { Dexamethasone, } \\
\text { insulin, ascorbate } \\
\text { phosphate, TGF- } \beta 3 \text {, } \\
\text { bFGF, and } 10 \% \text { FBS. }\end{array}$ & 2,4 , and 8 weeks & 3 & No & $\begin{array}{c}\text { SHED showed } \\
\text { colony-forming capacity, } \\
\text { odonto/osteogenic, and } \\
\text { adipogenic differentiation } \\
\text { capacity. }\end{array}$ \\
\hline $\begin{array}{l}\text { Rizk et al. [175]. } \\
\text { (2013) }\end{array}$ & $\begin{array}{c}\text { Cartilage-like } \\
\text { constructs from } \\
\text { DP-MSCs with TGF- } \beta 3 \\
\text { transduction in vivo } \\
\text { and in vitro }\end{array}$ & $\begin{array}{l}\text { Poly-L-lactic } \\
\text { acid/polyethylene }\end{array}$ & $\begin{array}{l}\text { DMEM media with } \\
\text { high glucose, insulin, } \\
\text { bovine serum } \\
\text { albumin, } \\
\text { dexamethason e, } \\
\text { ascorbate, and } \\
\text { recombinant human } \\
\text { TGF- } \beta 3\end{array}$ & $\begin{array}{c}7,14,30 \\
\text { days, and } 12 \text { weeks }\end{array}$ & 4 & TGF- $\beta 3$ & $\begin{array}{l}\text { Transduced DP-MSCs } \\
\text { highly expressed human } \\
\text { TGF } \beta 3 \text { for up to } 48 \text { days } \\
\text { and expressed } \\
\text { chondrogenic markers }\end{array}$ \\
\hline
\end{tabular}


Table 2. Cont

\begin{tabular}{|c|c|c|c|c|c|c|c|}
\hline Author & Objectives & Type of Scaffold & $\begin{array}{l}\text { Chondrogenic } \\
\text { Differentiation }\end{array}$ & Time Evaluation & Cell Passage & Growth Factor & Results \\
\hline $\begin{array}{l}\text { Hilkens et al. [176]. } \\
\text { (2013) }\end{array}$ & $\begin{array}{l}\text { Compare DP-MSCs } \\
\text { isolated by enzymatic } \\
\text { digestion with } \\
\text { DP-MSCs using the } \\
\text { explant method }\end{array}$ & No & $\begin{array}{c}\text { D-MEM/F12 } \\
\text { supplemented with } \\
1 \% \text { insulin transferrin } \\
\text { selenite and } \\
\text { chondrogenic } \\
\text { supplement }\end{array}$ & 3 weeks & 2 and 4 & TGF- $\beta 3$ & $\begin{array}{l}\text { DP-MSCs differentiate into } \\
\text { osteogenic and } \\
\text { chondrogenic lineages by } \\
\text { both methods }\end{array}$ \\
\hline $\begin{array}{l}\text { Dai et al. [177]. } \\
\text { (2012) }\end{array}$ & $\begin{array}{c}\text { Costal chondrocyte s as } \\
\text { a chondro- } \\
\text { inductive niche for } \\
\text { DP-MSCs in-vitro and } \\
\text { in-vivo }\end{array}$ & Fibrous PGA & $\begin{array}{c}\text { DMEM-F12 } \\
\text { supplemented with } \\
\text { 1\% ITS, ascorbate-2- } \\
\text { phosphate, proline, } \\
\text { dexamethasone, } \\
\text { TGF- } \beta 3\end{array}$ & 8 weeks & $\begin{array}{l}\text { P3 for DP-MSCs } \\
\text { and P2 for } \\
\text { chondrocytes }\end{array}$ & FGF9 & $\begin{array}{l}\text { STRO-1+ DP-MSCs consist } \\
\text { of several interrelated } \\
\text { subpopulations, which can } \\
\text { spontaneously } \\
\text { differentiate into } \\
\text { odontoblasts, osteoblasts, } \\
\text { and chondrocytes. }\end{array}$ \\
\hline $\begin{array}{l}\text { Yu et al. [125]. } \\
\text { (2010) }\end{array}$ & $\begin{array}{l}\text { Differentiation } \\
\text { potential of DP-MSCs } \\
\text { at different passages }\end{array}$ & $\begin{array}{l}\text { Absorbale gelatin } \\
\text { sponges }\end{array}$ & No & $\mathrm{P} 1 \times \mathrm{P} 9$ & 1 and 9 & No & $\begin{array}{l}\text { DPSCs at the 9th passage } \\
\text { restrict their differentiation } \\
\text { potential to the osteoblast } \\
\text { lineage in vivo. }\end{array}$ \\
\hline
\end{tabular}


Table 3. In-vivo chondrogenicity of MSCs of dental origin.

\begin{tabular}{|c|c|c|c|c|c|c|}
\hline Author & Animal model & Objectives & Type of Scaffold & Defect/Implantation & Time of Evaluation & Results \\
\hline $\begin{array}{l}\text { Fernandes et al. [170]. } \\
\text { (2018) }\end{array}$ & Miniature pig & $\begin{array}{l}\text { Animal model for } \\
\text { DP-MSCs for cartilage } \\
\text { evaluation }\end{array}$ & Collagen type I/III & $\begin{array}{l}\text { Knee/medial femoral } \\
\text { condyle }\end{array}$ & 6 weeks & $\begin{array}{l}\text { Animals tolerated the } \\
\text { procedure well and did not } \\
\text { show clinical or histological } \\
\text { rejection of the DP-MSCs }\end{array}$ \\
\hline Mata et al. [172]. (2017) & Rabbit & $\begin{array}{l}\text { Chondrogenic ability of } \\
\text { hDP-MSCs to regenerate } \\
\text { cartilage in vitro and } \\
\text { in vivo. }\end{array}$ & $3 \%$ alginate scaffold & Knee/trochlear groove & 3 months & $\begin{array}{l}\text { Complete regeneration of } \\
\text { cartilage was observed }\end{array}$ \\
\hline $\begin{array}{l}\text { Ishikawa et al. [173]. } \\
\text { (2016) }\end{array}$ & Mouse & $\begin{array}{l}\text { Therapeutic benefits of } \\
\text { SHED-CM for an } \\
\text { animal-induced arthritis } \\
\text { model }\end{array}$ & No & $\begin{array}{c}\text { No. Systemic } \\
\text { osteoarthritis model }\end{array}$ & 14 days & $\begin{array}{l}\text { SHED-CM inhibits osteoclast } \\
\text { differentiation and subsequent } \\
\text { bone destruction through } \\
\text { direct and indirect } \\
\text { mechanisms }\end{array}$ \\
\hline Chen et al. [174]. (2014) & Rat & $\begin{array}{l}\text { Chondrogenic potential of } \\
\text { SHEDs with TCP scaffold } \\
\text { in vitro and in vivo }\end{array}$ & $\beta$-tricalcium phosphate & $\begin{array}{l}\text { Dorsal midline dermal } \\
\text { space }\end{array}$ & $\begin{array}{l}2,4 \text {, and } \\
8 \text { weeks }\end{array}$ & $\begin{array}{c}\text { After in vivo transplantation, } \\
\text { SHED recombined with } \\
\beta \text {-TCP scaffolds were able to } \\
\text { generate new cartilage-like } \\
\text { tissues. }\end{array}$ \\
\hline Rizk et al. [175]. (2013) & Mice & $\begin{array}{l}\text { Cartilage-like constructs } \\
\text { from DP-MSCs with } \\
\text { TGF- } \beta 3 \text { transduction } \\
\text { in vivo and in vitro }\end{array}$ & $\begin{array}{l}\text { Poly-L-lactic } \\
\text { acid/polyethylene glycol } \\
\text { (PLLA/PEG) }\end{array}$ & Back of nude mice & $\begin{array}{c}7,14,30 \text { days, and } \\
12 \text { weeks }\end{array}$ & $\begin{array}{l}\text { Seeded on with scaffold, } \\
\text { DP-MSCs formed 3D cartilage } \\
\text { constructs in the area with } \\
\text { cartilage defects. }\end{array}$ \\
\hline Dai et al. [177]. (2012) & Mice & $\begin{array}{l}\text { Costal chondrocyte s as } \\
\text { chondro- inductive niche } \\
\text { for DP-MSCs in vitro and } \\
\text { in vivo }\end{array}$ & $\begin{array}{l}\text { Fibrous polyglycolic acid } \\
\text { (PGA) }\end{array}$ & Back of nude mice & 8 weeks & $\begin{array}{l}\text { The differentiation capacity of } \\
\text { DP-MSCs changes during cell } \\
\text { passaging, and DPSCs at the } \\
\text { 9th passage restrict their } \\
\text { differentiation potential to the } \\
\text { osteoblast lineage in vivo }\end{array}$ \\
\hline Yu et al. [125]. (2010) & Rat & $\begin{array}{c}\text { Differentiation potential of } \\
\text { STRO- } 1^{+} \text {DP-MSCs at } \\
\text { different passages }\end{array}$ & $\begin{array}{l}\text { Absorbable gelatin } \\
\text { sponges }\end{array}$ & Renal capsule & $\begin{array}{l}14 \text { days posttrans } \\
\text { plantation }\end{array}$ & $\begin{array}{l}\text { In vivo transplantation results } \\
\text { showed that rat DPSC-P1 cell } \\
\text { pellets developed into dentin, } \\
\text { bone, and cartilage structures, } \\
\text { respectively. }\end{array}$ \\
\hline
\end{tabular}




\section{Engineered Chondrogenesis by D-MSCs}

Due to the intrinsic limited potential of cartilage tissue to heal, cartilage tissue engineering gave a robust breakthrough in the field of regenerative and translational medicine. The field of tissue engineering provides the biological substitute of limited available tissues to restore and maintain the naive homeostasis and to improve the biomechanical strength and function of the tissues. The integral components of tissue engineering are stem/stromal cells, scaffolds, and bio-micromolecules [178-180]. The successfully engineered tissue relies on tissue ergonomics that include harvest and expansion of appropriate cells, the addition of optimum levels of growth factors and cytokines, and provision of 3D scaffold and extracellular matrices until the healing gets completed.

Growth factors: The cardinal growth factors responsible for cartilage engineering are TGF- $\beta 1$ and $-\beta 3$, BMP- 2 and -7 , IGF- 1 , and bFGF. TGF- $\beta 1$ induces and maintains chondrogenesis of MSC through chondrostimulatory signaling by p38, ERK-1, JNK, N-cadherin expression, and suppresses the IL- 1 catabolism [181]. TGF- $\beta 1$ controls Wnt-mediated signaling and $\beta$-catenin TCF pathway in early MSC chondrogenesis [182]. TGF- $\beta 3$, when co-cultured with bovine MSCs in a chitosan scaffold, stimulates the growth of hyaline cartilage and integrates into the host cartilage [183]. BMPs are involved in Hedgehog and TGF$\beta$ signaling in regulating chondrogenesis both in vitro and in vivo [184-186]. BMP-2 inhibits IL-1 effects and enhances cartilage cell production by inducing chondrogenic factors, whereas BMP-7 enhances ECM production [187]. IGF-1 downregulates MMP-13 by upregulating collagen 2 expression and GAG synthesis [188]. IGF-1 induces in vitro and in vivo chondrogenesis in a dose- and time-dependent manner [189]. The evidence stated that bFGF-18 in a concentration-dependent manner stimulates and enhances chondrogenesis in the osteochondral lesion of rabbit knees [190,191].

Bioactive molecules: Kartogenin (KGN) enhances MSC chondrogenesis by upregulation of CBF $\beta$-RUNX1 transcription [192]. Evidence states that kartogenin promotes tendon and meniscus regeneration $[193,194]$. KGN inhibits pain stimulus, attenuates chondral degeneration and inflammation, supplements the biomechanical strength of repaired bones and tendons in-vivo animals, and robust chondrogenic differentiation of DP-MSCs [195]. Simvastatin, a hypolipidaemic molecule, enhances positive effects on synovium and cartilage tissues, thereby reducing inflammation, degeneration and halts arthritis progression [196]. A higher concentration of statins decreased the production of nitric oxide in chondrocytes and cartilage explants [197].

Bioactive scaffolds: Scaffolds, an integral part of tissue engineering, are of natural [collagen, fibrin, hyaluronan, alginate, agarose, and chitosan] and synthetic [polylactic acid (PLA), polyglycolic acid (PGA), and copolymer polylactic-co-glycolic acid (PLGA)] polymers. The ideal scaffold should be biocompatible, optimum porosity, biodegradable, elastic natured, mechanical strength, easy fabrication, non-toxic, long-term effectiveness, and support cell attachment and proliferation $[198,199]$. Platelet-rich plasma seeded with agarose enhance cartilage and tendon regeneration [200]. MSCs cocultured with collagen or agarose enhance chondrocyte differentiation along with increased production of ECM and GAGs [201]. Alginate, an injectable scaffold, is used in regenerating focal chondral defects and in autologous chondrocyte implantation [202,203]. DP-MSCs accelerate chondrogenesis when cultured with growth factors and alginate beads [204]. The synergistic effects of chitosan and hyaluronic acid hydrogel enhance the healing of cartilage defects in rabbits [205]. Synthetic polymer scaffolds are used in the repair of osteochondral defects in rabbits [206] and meniscal lesions in dogs [207].

Chondrocytes release factor XIIIA, whose upregulation leads to hypertrophic chondrocyte differentiation in OA chondrocytes. In the murine OA cartilage model, there is an interplay between FXIIIA and $\alpha 1$ subunit of $\alpha 1 \beta 1$ integrin and tissue glutaminase 2 (TG2) mobilization, which leads to remodeling of the cartilage matrix. In absence of TG2, FXIIIA fails to undergo chondrocyte hypertrophy [208]. The conjunction of plasma membranebound TG2 and FXIIIA with a raised expression of FXIIIA upregulates the p38 MAP kinase signaling pathway in chondrocytes of OA cartilage in situ [209]. In turn, p38 signaling sig- 
nificantly increases SOX-9, which inhibits both in vitro and in vivo chondrocyte maturation to hypertrophy by DP-MSC-induced chondrogenesis [210].

Cordycepin is a potent antioxidant molecule with anti-tumorigenic and anti-inflammatory properties [211]. During MSC-induced chondrogenesis, cordycepin upregulates type $2 \mathrm{col}$ lagen, SOX-9, and TGF- $\beta 1$ and $-\beta 3$ expression, whereas downregulates type 10 collagen and Runx-2 [162]. Cordycepin has the potential to construct engineered cartilage by the inhibition of chondrocyte hypertrophy through PI3K/Bapx1 and the westin signaling pathway [212]. Hence, cordycepin plays a major role in cartilage and chondrocyte metabolism.

DP-MSCs loaded onto nanostructured PEG-GELMA-HA hydrogel form 3D spheroids, which further differentiate into chondrocytes in vitro [61]. Scaffold-assisted chondrogenesis upregulates procollagen type 2 and 10, aggrecan, alkaline phosphatase, and SOX-9 genes and downregulates Nanog, Slug, Snail, and Twist genes [172,213]. IHC analysis exhibit type 2 collagen deposition in DP-MSCs co-cultured with PEG-GELMA-HA hydrogel scaffold. These findings direct the usage of DP-MSCs to construct engineered cartilage in focal cartilage and osteochondral defects.

Expanded chondrocytes from MSCs co-cultured with PGA-fibrin scaffolds revealed considerable expression of type 1 and 2 collagen and further resulted in the formation of hyaline cartilage. Upon optimal addition of platelet-rich plasma to cartilage tissue, the formation of hyaline cartilage was robust with higher expression of collagen type 2 [214].

Loading of human dedifferentiated chondrocytes into collagen sponge, in the presence of hypoxia and BMP-2, resulted in chondrogenesis, which is transfected onto siRNAs targeting collagen type 1 and HtrA1 serine protease, which are raised in OA cartilage. Such a mechanism led to the improvement of chondrocyte phenotype differentiation. Transplantation of in vitro cultured cells into nude mouse model in vivo resulted in neochondrogenesis with hyaline matrix formation [215]. The in vitro and in vivo studies on cartilage tissue engineering using stem cells of dental origin are tabulated in Tables 4 and 5.

Table 4. In vitro studies on cartilage tissue engineering using stem cells of dental origin.

\begin{tabular}{|c|c|c|}
\hline Author & Methods & Main Results \\
\hline Fernandes et al. [170]. (2018) & Transmission electron microscopy & $\begin{array}{c}\text { MSCs derived from dental pulp had intact } \\
\text { membranes and scattered microvilli-like structures } \\
\text { on their surfaces, showing good attachment to the } \\
\text { biomaterial scaffold. }\end{array}$ \\
\hline \multirow[b]{2}{*}{ Westin et al. [171]. (2017) } & $\begin{array}{l}\text { Indirect toxicity of } \\
\text { scaffolds to DP-MSCs }\end{array}$ & $\begin{array}{l}\text { Biomaterial produced is not capable of affecting the } \\
\text { growth of DP-MSCs }\end{array}$ \\
\hline & Histology & $\begin{array}{l}\text { The formation of collagen fibers by } \\
\text { DP-MSCs in culture can be observed, confirming } \\
\text { that DP-MSCs were able to effectively differentiate } \\
\text { into chondrocytes within the cultured matrix }\end{array}$ \\
\hline Mata et al. [172]. (2017) & Chondrocyte differentiation & $\begin{array}{l}\text { Chondrocytes and hDP-MSCs grown in chondral } \\
\text { differentiation medium showed a rounded } \\
\text { morphology that correlated with significant } \\
\text { expression of COLII and ACAN. }\end{array}$ \\
\hline Ishikawa et al. [173]. (2016) & $\begin{array}{l}\text { Evaluation of SHED-CM potential for } \\
\text { inhibition of osteoclastogenesis and M2 } \\
\text { macrophage induction }\end{array}$ & $\begin{array}{l}\text { BMCs cultured in SHED-CM underwent reduced } \\
\text { osteoclast differentiation; } \\
\text { Increased number of CD } 206^{+} \text {macrophages with } \\
\text { upregulation of CD206 and arginase genes in } \\
\text { SHED-CM }\end{array}$ \\
\hline \multirow[t]{2}{*}{ Chen et al. [174]. (2014) } & Chondrogenic differentiation of SHED & $\begin{array}{l}\text { Confirmation of chondrogenic differentiation of } \\
\text { SHED by toluidine blue staining, safranin O staining, } \\
\text { type II collagen, and aggrecan immunostaining }\end{array}$ \\
\hline & $\begin{array}{l}\text { SHED and TCP analysis by scanning } \\
\text { electron micrography }\end{array}$ & Rich ECM was secreted by SHED on day 7 with TCP \\
\hline
\end{tabular}


Table 4. Cont.

\begin{tabular}{|c|c|c|}
\hline Author & Methods & Main Results \\
\hline Fernandes et al. [170]. (2018) & Transmission electron microscopy & $\begin{array}{c}\text { MSCs derived from dental pulp had intact } \\
\text { membranes and scattered microvilli-like structures } \\
\text { on their surfaces, showing good attachment to the } \\
\text { biomaterial scaffold. }\end{array}$ \\
\hline \multirow[b]{2}{*}{ Rizk et al. [175]. (2013) } & $\begin{array}{l}\text { Cytologic evaluation of DP-MSCs } \\
\text { in vitro }\end{array}$ & $\begin{array}{l}\text { TGF- } \beta 3 \text {-transduced DP-MSCs formed well-defined } \\
\text { micro masses }\end{array}$ \\
\hline & $\begin{array}{l}\text { DP-MSCs and scaffolds in vitro by } \\
\text { scanning electron microscopy }\end{array}$ & $\begin{array}{c}\text { Increases in type IIA collagen, aggrecan, and SOX-9 } \\
\text { in both TGF- } \beta 3 \text { - transduced DP-MSCs and those } \\
\text { supplied with TGF- } \beta 3 \text {. }\end{array}$ \\
\hline \multirow[b]{2}{*}{ Hilkens et al. [176]. (2013) } & Morphology & Heterogeneous cell culture \\
\hline & $\begin{array}{l}\text { Immunophenotype, proliferation rate, } \\
\text { adipogenic, osteogenic, and } \\
\text { chondrogenic differentiation }\end{array}$ & $\begin{array}{c}\text { Immunophenotype, proliferation rate, and } \\
\text { adipogenic, osteogenic, or chondrogenic } \\
\text { differentiation showed no significant difference } \\
\text { between groups }\end{array}$ \\
\hline \multirow{2}{*}{$\begin{array}{l}\text { Dai et al. [177]. } \\
\qquad(2012)\end{array}$} & In vitro analysis & $\begin{array}{l}\text { Cultured chondrocytes enhance the expression of } \\
\text { SOX-9, ACAN, and COL2 and downregulate the } \\
\text { expression of the early hypertrophic marker COL10 }\end{array}$ \\
\hline & $\begin{array}{l}\text { Markers in DP-MSCs in response to } \\
\text { FGF9 or CM. }\end{array}$ & $\begin{array}{l}\text { Intense FGFR3 staining and strong phosphorylation } \\
\text { of ERK1/2 staining in monolayer DP-MSCs cultured } \\
\text { in CM with FGF9. }\end{array}$ \\
\hline Yu et al. [125]. (2010) & In vitro analysis & $\begin{array}{c}\text { DP-MSCs differentiation markers showed significant } \\
\text { upregulation in the 9th passage. }\end{array}$ \\
\hline
\end{tabular}

Table 5. In vivo studies on cartilage tissue engineering using stem cells of dental origin.

\begin{tabular}{|c|c|c|}
\hline Author & Methods & Main Results \\
\hline Fernandes et al. [170]. (2019) & $\begin{array}{c}\text { Macroscopic and histological } \\
\text { evaluation }\end{array}$ & $\begin{array}{l}\text { Scaffolds plus DP-MSCs showed coverage of the } \\
\text { defect and new tissue growth over the cartilage. } \\
\text { Scaffold alone showed a regular defect border and } \\
\text { shallow tissue coverage over the defect. }\end{array}$ \\
\hline \multirow{2}{*}{$\begin{array}{l}\text { Mata et al. [172]. } \\
\qquad(2017)\end{array}$} & Macroscopic evaluation & $\begin{array}{l}\text { The loss of cartilage was diminished in animals } \\
\text { implanted with alginate containing either } \\
\text { chondrocytes or hDP-MSCs. }\end{array}$ \\
\hline & Immunochemistry & $\begin{array}{l}\text { Higher expression of type II collagen with no } \\
\text { significant expression of type I collagen in groups } \\
\text { with chondrocytes and hDP-MSCs. }\end{array}$ \\
\hline \multirow{3}{*}{$\begin{array}{c}\text { Ishikawa } \\
\text { et al. [173]. (2016) }\end{array}$} & Clinical finding-Edema & $\begin{array}{l}\text { SHED-CM-treated mice exhibited minimal paw } \\
\text { swelling, while DMEM- and BMSC-CM-treated mice } \\
\text { displayed severe and moderate swelling } \\
\text { encompassing the ankle, foot, and digits }\end{array}$ \\
\hline & Histological evaluation & $\begin{array}{l}\text { Quantitative histological scores of synovial } \\
\text { inflammation, bone erosion, and cartilage damage } \\
\text { were all significantly lower in SHED-CM-treated } \\
\text { mice than in the BMSC-CM- or DMEM-treated mice }\end{array}$ \\
\hline & Immunohistochemistry & $\begin{array}{l}\text { SHED-CM and BMSC-CM groups reduced the } \\
\text { proportion of iNOS+F4/80+ M1 cells, and the } \\
\text { proportion of CD206+F4/80+ M2 cells was increased } \\
\text { in the SHED-CM group, but not the } \\
\text { BMSC-CM group. }\end{array}$ \\
\hline
\end{tabular}


Table 5. Cont.

\begin{tabular}{|c|c|c|}
\hline Author & Methods & Main Results \\
\hline \multirow{2}{*}{ Chen et al. [174]. (2014) } & Histological evaluation & $\begin{array}{l}\text { SHED produces rich ECM on day } 7 \text { with } \\
\beta \text {-tricalcium phosphate }\end{array}$ \\
\hline & Immunohistochemistry & $\begin{array}{l}\text { Cartilage-like tissue stained positive for } \\
\text { type II collagen }\end{array}$ \\
\hline \multirow{2}{*}{ Rizk et al. [175]. (2013) } & Western blot analysis & $\begin{array}{l}\text { Expression of collagen II, Sox9, and aggrecan in } \\
\text { constructs seeded with TGF- } \beta 3 \text { - transduced cells }\end{array}$ \\
\hline & RT-PCR & $\begin{array}{l}\text { TGF- } \beta 3 \text {-transduced DP-MSCs exhibited an } \\
\text { increased expression of collagen II }\end{array}$ \\
\hline Dai et al. [177]. (2012) & $\begin{array}{l}\text { Histological evaluation of cellular } \\
\text { morphology and GAG quantification }\end{array}$ & $\begin{array}{c}\text { Co-cultured DP-MSCs with cultured chondrocyte } \\
\text { transplants were larger and had increased } \\
\text { cartilaginous matrix deposition and higher } \\
\text { GAG quantification }\end{array}$ \\
\hline Yu et al. [125]. (2010) & $\begin{array}{l}\text { Histology evaluation of } \\
\text { STRO1+DP-MSCs } \\
\text { in transplanted P1 and P9 pellets }\end{array}$ & $\begin{array}{l}\text { Eat DP-MSC-P1 cell pellets developed into dentin, } \\
\text { bone, and cartilage structures, while DP-MSC-P9 } \\
\text { cells could only generate bone tissues. }\end{array}$ \\
\hline
\end{tabular}

\section{Future Perspectives}

The U.S. Army has invested over $\$ 250$ million towards stem cell research to aid in the management of their injured soldiers in the field through a project called Armed Forces Institute for Regenerative Medicine. In recognition of the regenerative potential of dental stem cells, a trend towards establishing tooth banks is on the rise in developed and developing countries [216-219]. More research is directed towards their application in cardiac ailments [220], regenerating brain tissue [221], muscular dystrophy [222], and bone regeneration [223]. With the pursuit towards their regenerative potential, future clinical studies are needed to validate the results of various animal model and in vitro studies to prove the concept of chondrogenic differentiation of the implanted MSCs of dental origin to be of use in various common clinical conditions such as osteoarthritis that leads to cartilage degeneration.

\section{Conclusions}

MSC-based therapies are the upcoming biological modality of management of various ailments in the current decade. Having discussed the potential of the various dentalderived stem cells towards various regenerative domains including dental pulp stem cells towards chondrogenesis, their potential for future utility in mitigating various pathomechanisms and restoring the normal homeostasis needs further exploration. Future clinical studies are needed to evaluate their effectiveness in varied clinical scenarios to enable practical utility. With the evolution of the understanding of these cell-based regenerative therapies, dental tissue-derived cells would prove to be a more promising tool in the management of various diseases and help in the further advancement of medicine in the future.

Author Contributions: Conception and design: M.J., S.M.; Administrative support: M.K.; Provision of study materials or patients: M.J., S.M.; Collection and assembly of data: N.J., G.S.P.; Data analysis and interpretation: S.M., M.J.; Manuscript writing: All authors; Final approval of manuscript: All authors. All authors have read and agreed to the published version of the manuscript.

Funding: This research received no specific grant from any funding agency in the public, commercial, or not-for-profit sectors.

Institutional Review Board Statement: Not applicable.

Informed Consent Statement: Not applicable. 


\section{Data Availability Statement: Not applicable.}

Conflicts of Interest: The authors declared no potential conflicts of interest concerning the research, authorship, and/or publication of this article.

\section{References}

1. Krishnan, Y.; Grodzinsky, A.J. Cartilage diseases. Matrix Biol. 2018, 71-72, 51-69. [CrossRef]

2. Sophia Fox, A.J.; Bedi, A.; Rodeo, S.A. The basic science of articular cartilage. Sports Health 2009, 1, 461-468. [CrossRef]

3. Baugé, C.; Boumédiene, K. Use of adult stem cells for cartilage tissue engineering: Current status and future developments. Stem Cells Int. 2015, 2015, e438026. [CrossRef] [PubMed]

4. Ramesh, R.; Jeyaraman, M.; Chaudhari, K.; Dhamsania, H.J.; Prajwal, G.S. Mesenchymal stem cells-A boon to orthopedics. Open J. Regen. Med. 2018, 7, 19-27. [CrossRef]

5. Howard, D.; Buttery, L.D.; Shakesheff, K.M.; Roberts, S.J. Tissue engineering: Strategies, stem cells and scaffolds. J. Anat. 2008, 213, 66-72. [CrossRef] [PubMed]

6. Kessler, M.W.; Grande, D.A. Tissue engineering and cartilage. Organogenesis 2008, 4, 28-32. [CrossRef]

7. Almouemen, N.; Kelly, H.M.; O'Leary, C. Tissue engineering: Understanding the role of biomaterials and biophysical forces on cell functionality through computational and structural biotechnology analytical methods. Comput. Struct. Biotechnol. J. 2019, 17, 591-598. [CrossRef] [PubMed]

8. Vinatier, C.; Guicheux, J. Cartilage tissue engineering: From biomaterials and stem cells to osteoarthritis treatments. Ann. Phys. Rehabil. Med. 2016, 59, 139-144. [CrossRef] [PubMed]

9. Mehrabani, D.; Mojtahed Jaberi, F.; Zakerinia, M.; Hadianfard, M.J.; Jalli, R.; Tanideh, N.; Zare, S. The healing effect of bone marrow-derived stem cells in knee osteoarthritis: A case report. World J. Plast. Surg. 2016, 5, 168-174.

10. Pak, J.; Lee, J.H.; Pak, N.; Pak, Y.; Park, K.S.; Jeon, J.H.; Jeong, B.C.; Lee, S.H. Cartilage regeneration in humans with adipose tissue-derived stem cells and adipose stromal vascular fraction cells: Updated status. Int. J. Mol. Sci. 2018, 19, 2146. [CrossRef] [PubMed]

11. Mohamed, N.S.; Wilkie, W.A.; Remily, E.A.; Delanois, R.E. Can human placental extract help patients with osteoarthritis? Ann. Transl. Med. 2020, 8. [CrossRef]

12. Huddleston, H.P.; Cohn, M.R.; Haunschild, E.D.; Wong, S.E.; Farr, J.; Yanke, A.B. Amniotic product treatments: Clinical and basic science evidence. Curr. Rev. Musculoskelet. Med. 2020, 13, 148-154. [CrossRef]

13. Cheng, J.-H.; Wang, C.-J.; Chou, W.-Y.; Hsu, S.-L.; Chen, J.-H.; Hsu, T.-C. Comparison efficacy of ESWT and Wharton's jelly mesenchymal stem cell in early osteoarthritis of rat knee. Am. J. Transl. Res. 2019, 11, 586-598. [PubMed]

14. Liang, H.; Suo, H.; Wang, Z.; Feng, W. Progress in the treatment of osteoarthritis with umbilical cord stem cells. Hum. Cell 2020, 33, 470-475. [CrossRef] [PubMed]

15. Li, N.; Gao, J.; Mi, L.; Zhang, G.; Zhang, L.; Zhang, N.; Huo, R.; Hu, J.; Xu, K. Synovial membrane mesenchymal stem cells: Past life, current situation, and application in bone and joint diseases. Stem Cell Res. Ther. 2020, 11, 381. [CrossRef] [PubMed]

16. Bahney, C.S.; Miclau, T. Therapeutic potential of stem cells in orthopedics. Indian J. Orthop. 2012, 46, 4-9. [CrossRef]

17. Bansal, R.; Jain, A. Current overview on dental stem cells applications in regenerative dentistry. J. Nat. Sci. Biol. Med. 2015, 6, 29-34. [CrossRef]

18. Xudong, G.; Zhengguo, C. Gingiva-derived mesenchymal stem cells and their potential applications in oral and maxillofacial diseases. Curr. Stem Cell Res. Ther. 2019, 15, 43-53.

19. Scheller, E.L.; Krebsbach, P.H.; Kohn, D.H. Tissue engineering: State of the art in oral rehabilitation. J. Oral Rehabil. 2009, 36, 368-389. [CrossRef]

20. Giai Via, A.; Frizziero, A.; Oliva, F. Biological properties of mesenchymal stem cells from different sources. Muscles Ligaments Tendons J. 2012, 2, 154-162.

21. Spees, J.L.; Lee, R.H.; Gregory, C.A. Mechanisms of mesenchymal stem/stromal cell function. Stem Cell Res. Ther. 2016, 7, 125. [CrossRef] [PubMed]

22. Robert, A.W.; Marcon, B.H.; Dallagiovanna, B.; Shigunov, P. Adipogenesis, osteogenesis, and chondrogenesis of human mesenchymal stem/stromal cells: A comparative transcriptome approach. Front. Cell Dev. Biol. 2020, 8, 561. [CrossRef] [PubMed]

23. Andrzejewska, A.; Lukomska, B.; Janowski, M. Concise review: Mesenchymal stem cells: From roots to boost. Stem Cells 2019, 37, 855-864. [CrossRef]

24. Rodríguez-Fuentes, D.E.; Fernández-Garza, L.E.; Samia-Meza, J.A.; Barrera-Barrera, S.A.; Caplan, A.I.; Barrera-Saldaña, H.A. Mesenchymal stem cells current clinical applications: A systematic review. Arch. Med Res. 2021, 52, 93-101. [CrossRef]

25. Goldring, M.B. Chondrogenesis, chondrocyte differentiation, and articular cartilage metabolism in health and osteoarthritis. Ther. Adv. Musculoskelet. Dis. 2012, 4, 269-285. [CrossRef]

26. Goldring, M.B. Chondrogenesis, joint formation, and cartilage metabolism. Arthritis Res. Ther. 2012, 14, A5. [CrossRef]

27. Chalisserry, E.P.; Nam, S.Y.; Park, S.H.; Anil, S. Therapeutic potential of dental stem cells. J. Tissue Eng. 2017, 8, 2041731417702531. [CrossRef]

28. Aly, L.A.A. Stem cells: Sources, and regenerative therapies in dental research and practice. World J. Stem Cells 2015, 7, 1047-1053. [CrossRef] [PubMed] 
29. Ullah, I.; Subbarao, R.B.; Rho, G.J. Human mesenchymal stem cells-current trends and future prospective. Biosci. Rep. 2015, 35, e00191. [CrossRef] [PubMed]

30. Gao, F.; Chiu, S.M.; Motan, D.A.L.; Zhang, Z.; Chen, L.; Ji, H.-L.; Tse, H.-F.; Fu, Q.-L.; Lian, Q. Mesenchymal stem cells and immunomodulation: Current status and future prospects. Cell Death Dis. 2016, 7, e2062. [CrossRef]

31. Rajendran, R.; Gopal, S.; Masood, H.; Vivek, P.; Deb, K. Regenerative potential of dental pulp mesenchymal stem cells harvested from high caries patient's teeth. J. Stem Cells 2013, 8, 25-41. [PubMed]

32. Ledesma-Martínez, E.; Mendoza-Núñez, V.M.; Santiago-Osorio, E. Mesenchymal stem cells derived from dental pulp: A review. Stem Cells Int. 2016, 2016, 4709572. [CrossRef]

33. Miura, M.; Gronthos, S.; Zhao, M.; Lu, B.; Fisher, L.W.; Robey, P.G.; Shi, S. SHED: Stem cells from human exfoliated deciduous teeth. Proc. Natl. Acad. Sci. USA 2003, 100, 5807-5812. [CrossRef]

34. Ko, C.-S.; Chen, J.-H.; Su, W.-T. Stem cells from human exfoliated deciduous teeth: A concise review. Curr. Stem Cell Res. Ther. 2020, 15, 61-76. [CrossRef]

35. Zhao, Z.; Liu, J.; Weir, M.D.; Zhang, N.; Zhang, L.; Xie, X.; Zhang, C.; Zhang, K.; Bai, Y.; Xu, H.H.K. Human periodontal ligament stem cells on calcium phosphate scaffold delivering platelet lysate to enhance bone regeneration. RSC Adv. 2019, 9, 41161-41172. [CrossRef]

36. Song, I.S.; Han, Y.S.; Lee, J.-H.; Um, S.; Kim, H.Y.; Seo, B.M. Periodontal ligament stem cells for periodontal regeneration. Curr. Oral Health Rep. 2015, 2, 236-244. [CrossRef]

37. Zhang, J.; Ding, H.; Liu, X.; Sheng, Y.; Liu, X.; Jiang, C. Dental follicle stem cells: Tissue engineering and immunomodulation. Stem Cells Dev. 2019, 28, 986-994. [CrossRef]

38. Honda, M.J.; Imaizumi, M.; Tsuchiya, S.; Morsczeck, C. Dental follicle stem cells and tissue engineering. J. Oral Sci. 2010, 52, 541-552. [CrossRef] [PubMed]

39. Kang, J.; Fan, W.; Deng, Q.; He, H.; Huang, F. Stem cells from the apical papilla: A promising source for stem cell-based therapy. BioMed Res. Int. 2019, 2019, e6104738. [CrossRef] [PubMed]

40. Nada, O.A.; El Backly, R.M. Stem Cells from the Apical Papilla (SCAP) as a tool for endogenous tissue regeneration. Front. Bioeng. Biotechnol. 2018, 6, 103. [CrossRef]

41. Grawish, M.E. Gingival-derived mesenchymal stem cells: An endless resource for regenerative dentistry. World J. Stem Cells 2018, 10, 116-118. [CrossRef]

42. Venkatesh, D.; Kumar, K.P.M.; Alur, J.B. Gingival mesenchymal stem cells. J. Oral Maxillofac. Pathol. 2017, 21, 296-298. [CrossRef] [PubMed]

43. Alsulaimani, R.S.; Ajlan, S.A.; Aldahmash, A.M.; Alnabaheen, M.S.; Ashri, N.Y. Isolation of dental pulp stem cells from a single donor and characterization of their ability to differentiate after 2 years of cryopreservation. Saudi Med. J. 2016, 37, 551-560. [CrossRef] [PubMed]

44. Shi, X.; Mao, J.; Liu, Y. Pulp stem cells derived from human permanent and deciduous teeth: Biological characteristics and therapeutic applications. Stem Cells Transl. Med. 2020, 9, 445-464. [CrossRef]

45. Huang, G.T.-J.; Gronthos, S.; Shi, S. Mesenchymal stem cells derived from dental tissues vs. those from other sources. J. Dent. Res. 2009, 88, 792-806. [CrossRef]

46. Suchanek, J.; Nasry, S.A.; Soukup, T. The differentiation potential of human natal dental pulp stem cells into insulin-producing cells. Folia Biol. 2017, 63, 132-138.

47. Mortada, I.; Mortada, R.; Al Bazzal, M. Dental pulp stem cells and the management of neurological diseases: An update. J. Neurosci. Res. 2018, 96, 265-272. [CrossRef]

48. Sunil, P.; Manikandhan, R.; Muthu, M.; Abraham, S. Stem cell therapy in oral and maxillofacial region: An overview. J. Oral Maxillofac. Pathol. 2012, 16, 58-63. [CrossRef]

49. Fernandes, T.L.; Cortez de SantAnna, J.P.; Frisene, I.; Gazarini, J.P.; Gomes Pinheiro, C.C.; Gomoll, A.H.; Lattermann, C.; Hernandez, A.J.; Franco Bueno, D. Systematic review of human dental pulp stem cells for cartilage regeneration. Tissue Eng. Part B Rev. 2019, 26, 1-12. [CrossRef]

50. Ohkoshi, S.; Hara, H.; Hirono, H.; Watanabe, K.; Hasegawa, K. Regenerative medicine using dental pulp stem cells for liver diseases. World J. Gastrointest. Pharmacol. Ther. 2017, 8, 1-6. [CrossRef]

51. Gl, S.P.; Ramalingam, S.; Udhayakumar, Y. Human dental pulp stem cells and its applications in regenerative medicine-A literature review. J. Glob. Oral Heal. 2019, 2, 59-67. [CrossRef]

52. Ashri, N.Y.; Ajlan, S.A.; Aldahmash, A.M. Dental pulp stem cells. Saudi Med. J. 2015, 36, 1391-1399. [CrossRef]

53. Potdar, P.D.; Jethmalani, Y.D. Human dental pulp stem cells: Applications in future regenerative medicine. World J. Stem Cells 2015, 7, 839-851. [CrossRef] [PubMed]

54. Yasui, T.; Mabuchi, Y.; Morikawa, S.; Onizawa, K.; Akazawa, C.; Nakagawa, T.; Okano, H.; Matsuzaki, Y. Isolation of dental pulp stem cells with high osteogenic potential. Inflamm. Regen. 2017, 37, 8. [CrossRef]

55. Mortada, I.; Mortada, R. Dental pulp stem cells and osteogenesis: An update. Cytotechnology 2018, 70, 1479-1486. [CrossRef]

56. Gronthos, S.; Mankani, M.; Brahim, J.; Robey, P.G.; Shi, S. Postnatal human dental pulp stem cells (DPSCs) in vitro and in vivo. Proc. Natl. Acad. Sci. USA 2000, 97, 13625-13630. [CrossRef] [PubMed]

57. Yu, J.; Wang, Y.; Deng, Z.; Tang, L.; Li, Y.; Shi, J.; Jin, Y. Odontogenic capability: Bone marrow stromal stem cells versus dental pulp stem cells. Biol. Cell 2007, 99, 465-474. [CrossRef] [PubMed] 
58. Almushayt, A.; Narayanan, K.; Zaki, A.E.; George, A. Dentin matrix protein 1 induces cytodifferentiation of dental pulp stem cells into odontoblasts. Gene Ther. 2006, 13, 611-620. [CrossRef]

59. Achilleos, A.; Trainor, P.A. Neural crest stem cells: Discovery, properties and potential for therapy. Cell Res. 2012, 22, 288-304. [CrossRef]

60. Ibarretxe, G.; Crende, O.; Aurrekoetxea, M.; García-Murga, V.; Etxaniz, J.; Unda, F. Neural crest stem cells from dental tissues: A new hope for dental and neural regeneration. Stem Cells Int. 2012, 2012, 103503. [CrossRef]

61. Nemeth, C.L.; Janebodin, K.; Yuan, A.E.; Dennis, J.E.; Reyes, M.; Kim, D.-H. Enhanced chondrogenic differentiation of dental pulp stem cells using nanopatterned PEG-GelMA-HA hydrogels. Tissue Eng. Part A 2014, 20, 2817-2829. [CrossRef]

62. Moshaverinia, A.; Xu, X.; Chen, C.; Akiyama, K.; Snead, M.L.; Shi, S. Dental mesenchymal stem cells encapsulated in an alginate hydrogel co-delivery microencapsulation system for cartilage regeneration. Acta Biomater. 2013, 9, 9343-9350. [CrossRef]

63. Longoni, A.; Utomo, L.; van Hooijdonk, I.E.; Bittermann, G.K.; Vetter, V.C.; Kruijt Spanjer, E.C.; Ross, J.; Rosenberg, A.J.; Gawlitta, D. The chondrogenic differentiation potential of dental pulp stem cells. Eur. Cell Mater. 2020, 39, 121-135. [CrossRef]

64. Karaöz, E.; Demircan, P.C.; Sağlam, O.; Aksoy, A.; Kaymaz, F.; Duruksu, G. Human dental pulp stem cells demonstrate better neural and epithelial stem cell properties than bone marrow-derived mesenchymal stem cells. Histochem. Cell Biol. 2011, 136, 455-473. [CrossRef]

65. Rosa, V.; Dubey, N.; Islam, I.; Min, K.-S.; Nör, J.E. Pluripotency of stem cells from human exfoliated deciduous teeth for tissue engineering. Stem Cells Int. 2016, 2016, e5957806. [CrossRef]

66. Calloni, R.; Cordero, E.A.A.; Henriques, J.A.P.; Bonatto, D. Reviewing and updating the major molecular markers for stem cells. Stem Cells Dev. 2013, 22, 1455-1476. [CrossRef]

67. Rosa, V.; Botero, T.M.; Nör, J.E. Regenerative endodontics in light of the stem cell paradigm. Int. Dent. J. 2011, 61, 23-28. [CrossRef] [PubMed]

68. Shi, S.; Robey, P.G.; Gronthos, S. Comparison of human dental pulp and bone marrow stromal stem cells by cDNA microarray analysis. Bone 2001, 29, 532-539. [CrossRef]

69. Yamada, Y.; Ito, K.; Nakamura, S.; Ueda, M.; Nagasaka, T. Promising cell-based therapy for bone regeneration using stem cells from deciduous teeth, dental pulp, and bone marrow. Cell Transpl. 2011, 20, 1003-1013. [CrossRef] [PubMed]

70. Rao, N.; Wang, X.; Zhai, Y.; Li, J.; Xie, J.; Zhao, Y.; Ge, L. Stem cells from human exfoliated deciduous teeth ameliorate type II diabetic mellitus in Goto-Kakizaki rats. Diabetol. Metab. Syndr. 2019, 11, 22. [CrossRef] [PubMed]

71. Rao, N.; Wang, X.; Xie, J.; Li, J.; Zhai, Y.; Li, X.; Fang, T.; Wang, Y.; Zhao, Y.; Ge, L. Stem cells from human exfoliated deciduous teeth ameliorate diabetic nephropathy in vivo and in vitro by inhibiting advanced glycation end product-activated epithelialmesenchymal transition. Stem Cells Int. 2019, 2019, e2751475. [CrossRef]

72. Nicola, F.; Marques, M.R.; Odorcyk, F.; Petenuzzo, L.; Aristimunha, D.; Vizuete, A.; Sanches, E.F.; Pereira, D.P.; Maurmann, N.; Gonçalves, C.-A.; et al. Stem cells from human exfoliated deciduous teeth modulate early astrocyte response after spinal cord contusion. Mol. Neurobiol. 2019, 56, 748-760. [CrossRef]

73. Inoue, T.; Sugiyama, M.; Hattori, H.; Wakita, H.; Wakabayashi, T.; Ueda, M. Stem cells from human exfoliated deciduous tooth-derived conditioned medium enhance recovery of focal cerebral ischemia in rats. Tissue Eng. Part A 2013, 19, 24-29. [CrossRef] [PubMed]

74. Sugiyama, M.; Hattori, H.; Inoue, T.; Wakita, H.; Hibi, H.; Ueda, M. Stem cells from human exfoliated deciduous teeth enhance recovery from focal cerebral ischemia in rats. J. Oral Maxillofac. Surg. Med. Pathol. 2014, 26, 443-449. [CrossRef]

75. Zhu, S.; Min, D.; Zeng, J.; Ju, Y.; Liu, Y.; Chen, X. Transplantation of stem cells from human exfoliated deciduous teeth decreases cognitive impairment from chronic cerebral ischemia by reducing neuronal apoptosis in rats. Stem Cells Int. 2020, 2020, e6393075. [CrossRef]

76. Ueda, T.; Inden, M.; Ito, T.; Kurita, H.; Hozumi, I. Characteristics and therapeutic potential of dental pulp stem cells on neurodegenerative diseases. Front. Neurosci. 2020, 14, 407. [CrossRef] [PubMed]

77. Muhammad, S.A.; Nordin, N.; Hussin, P.; Mehat, M.Z.; Kasim, N.H.A.; Fakurazi, S. Protective effects of stem cells from human exfoliated deciduous teeth derived conditioned medium on osteoarthritic chondrocytes. PLoS ONE 2020, 15, e0238449. [CrossRef] [PubMed]

78. Zhu, W.; Liang, M. Periodontal ligament stem cells: Current status, concerns, and future prospects. Stem Cells Int. 2015, 2015, e972313. [CrossRef]

79. Iwasaki, K.; Komaki, M.; Yokoyama, N.; Tanaka, Y.; Taki, A.; Kimura, Y.; Takeda, M.; Oda, S.; Izumi, Y.; Morita, I. Periodontal ligament stem cells possess the characteristics of pericytes. J. Periodontol. 2013, 84, 1425-1433. [CrossRef]

80. Paduano, F.; Marrelli, M.; Palmieri, F.; Tatullo, M. CD146 expression influences periapical cyst mesenchymal stem cell properties. Stem Cell Rev. Rep. 2016, 12, 592-603. [CrossRef] [PubMed]

81. Wang, L.; Shen, H.; Zheng, W.; Tang, L.; Yang, Z.; Gao, Y.; Yang, Q.; Wang, C.; Duan, Y.; Jin, Y. Characterization of stem cells from alveolar periodontal ligament. Tissue Eng. Part A 2011, 17, 1015-1026. [CrossRef]

82. Silvério, K.G.; Rodrigues, T.L.; Coletta, R.D.; Benevides, L.; Da Silva, J.S.; Casati, M.Z.; Sallum, E.A.; Nociti, F.H. Mesenchymal stem cell properties of periodontal ligament cells from deciduous and permanent teeth. J. Periodontol. 2010, 81, 1207-1215. [CrossRef]

83. Andrukhov, O.; Behm, C.; Blufstein, A.; Rausch-Fan, X. Immunomodulatory properties of dental tissue-derived mesenchymal stem cells: Implication in disease and tissue regeneration. World J. Stem Cells 2019, 11, 604-617. [CrossRef] 
84. Zhou, L.; Liu, W.; Wu, Y.; Sun, W.; Dörfer, C.E.; Fawzy El-Sayed, K.M. Oral mesenchymal stem/progenitor cells: The immunomodulatory masters. Stem Cells Int. 2020, 2020, e1327405. [CrossRef]

85. Zhou, T.; Pan, J.; Wu, P.; Huang, R.; Du, W.; Zhou, Y.; Wan, M.; Fan, Y.; Xu, X.; Zhou, X.; et al. Dental follicle cells: Roles in development and beyond. Stem Cells Int. 2019, 2019, e9159605. [CrossRef]

86. Mori, G.; Ballini, A.; Carbone, C.; Oranger, A.; Brunetti, G.; Di Benedetto, A.; Rapone, B.; Cantore, S.; Di Comite, M.; Colucci, S.; et al. Osteogenic differentiation of dental follicle stem cells. Int. J. Med. Sci. 2012, 9, 480-487. [CrossRef] [PubMed]

87. Human Dental Follicle Cells Express Embryonic, Mesenchymal and Neural Stem Cells Markers-PubMed. Available online: https:/ / pubmed.ncbi.nlm.nih.gov/27764680/ (accessed on 28 March 2021).

88. Rezai-Rad, M.; Bova, J.F.; Orooji, M.; Pepping, J.; Qureshi, A.; Del Piero, F.; Hayes, D.; Yao, S. Evaluation of bone regeneration potential of dental follicle stem cells for treatment of craniofacial defects. Cytotherapy 2015, 17, 1572-1581. [CrossRef]

89. Veernala, I.; Giri, J.; Pradhan, A.; Polley, P.; Singh, R.; Yadava, S.K. Effect of fluoride doping in laponite nanoplatelets on osteogenic differentiation of human dental follicle stem cells (hDFSCs). Sci. Rep. 2019, 9, 915. [CrossRef]

90. Sonoyama, W.; Liu, Y.; Yamaza, T.; Tuan, R.S.; Wang, S.; Shi, S.; Huang, G.T.-J. Characterization of the apical papilla and its residing stem cells from human immature permanent teeth: A pilot study. J. Endod. 2008, 34, 166-171. [CrossRef] [PubMed]

91. Huang, G.T.-J.; Yamaza, T.; Shea, L.D.; Djouad, F.; Kuhn, N.Z.; Tuan, R.S.; Shi, S. Stem/progenitor cell-mediated de novo regeneration of dental pulp with newly deposited continuous layer of dentin in an in vivo model. Tissue Eng. Part A 2010, 16, 605-615. [CrossRef] [PubMed]

92. Dong, R.; Yao, R.; Du, J.; Wang, S.; Fan, Z. Depletion of histone demethylase KDM2A enhanced the adipogenic and chondrogenic differentiation potentials of stem cells from apical papilla. Exp. Cell Res. 2013, 319, 2874-2882. [CrossRef] [PubMed]

93. Bakopoulou, A.; Leyhausen, G.; Volk, J.; Koidis, P.; Geurtsen, W. Comparative characterization of STRO-1neg/CD146pos and STRO-1pos/CD146pos apical papilla stem cells enriched with flow cytometry. Arch. Oral Biol. 2013, 58, 1556-1568. [CrossRef] [PubMed]

94. Hilkens, P.; Bronckaers, A.; Ratajczak, J.; Gervois, P.; Wolfs, E.; Lambrichts, I. The angiogenic potential of DPSCs and SCAPs in an in vivo model of dental pulp regeneration. Stem Cells Int. 2017, 2017, e2582080. [CrossRef]

95. Wu, J.; Huang, G.T.-J.; He, W.; Wang, P.; Tong, Z.; Jia, Q.; Dong, L.; Niu, Z.; Ni, L. Basic fibroblast growth factor enhances stemness of human stem cells from the apical papilla. J. Endod. 2012, 38, 614-622. [CrossRef] [PubMed]

96. Abuarqoub, D.; Awidi, A.; Abuharfeil, N. Comparison of osteo/odontogenic differentiation of human adult dental pulp stem cells and stem cells from apical papilla in the presence of platelet lysate. Arch. Oral Biol. 2015, 60, 1545-1553. [CrossRef]

97. Sonoyama, W.; Liu, Y.; Fang, D.; Yamaza, T.; Seo, B.-M.; Zhang, C.; Liu, H.; Gronthos, S.; Wang, C.-Y.; Wang, S.; et al. Mesenchymal stem cell-mediated functional tooth regeneration in swine. PLoS ONE 2006, 1, e79. [CrossRef]

98. Jeon, B.-G.; Kang, E.-J.; Kumar, B.M.; Maeng, G.-H.; Ock, S.-A.; Kwack, D.-O.; Park, B.-W.; Rho, G.-J. Comparative analysis of telomere length, telomerase and reverse transcriptase activity in human dental stem cells. Cell Transpl. 2011, 20, 1693-1705. [CrossRef] [PubMed]

99. Yu, S.; Zhao, Y.; Ma, Y.; Ge, L. Profiling the secretome of human stem cells from dental apical papilla. Stem Cells Dev. 2016, 25, 499-508. [CrossRef] [PubMed]

100. Yang, H.; Cao, Y.; Zhang, J.; Liang, Y.; Su, X.; Zhang, C.; Liu, H.; Han, X.; Ge, L.; Fan, Z. DLX5 and HOXC8 enhance the chondrogenic differentiation potential of stem cells from apical papilla via LINC01013. Stem Cell Res. Ther. 2020, $11,271$. [CrossRef]

101. Stefańska, K.; Mehr, K.; Wieczorkiewicz, M.; Kulus, M.; Angelova Volponi, A.; Shibli, J.A.; Mozdziak, P.; Skowroński, M.T.; Antosik, P.; Jaśkowski, J.M.; et al. Stemness potency of human gingival cells-Application in anticancer therapies and clinical trials. Cells 2020, 9, 1916. [CrossRef]

102. Fournier, B.P.J.; Larjava, H.; Häkkinen, L. Gingiva as a source of stem cells with therapeutic potential. Stem Cells Dev. 2013, 22, 3157-3177. [CrossRef]

103. Zhang, Q.; Shi, S.; Liu, Y.; Uyanne, J.; Shi, Y.; Shi, S.; Le, A.D. Mesenchymal stem cells derived from human gingiva are capable of immunomodulatory functions and ameliorate inflammation-related tissue destruction in experimental colitis. J. Immunol. 2009, 183, 7787-7798. [CrossRef]

104. Tang, L.; Li, N.; Xie, H.; Jin, Y. Characterization of mesenchymal stem cells from human normal and hyperplastic gingiva. J. Cell Physiol. 2011, 226, 832-842. [CrossRef] [PubMed]

105. Human Gingiva-Derived Mesenchymal Stem Cells Elicit Polarization of m2 Macrophages and Enhance Cutaneous Wound Healing_PubMed. Available online: https:/ / pubmed.ncbi.nlm.nih.gov/20734355/ (accessed on 28 March 2021).

106. Moshaverinia, A.; Xu, X.; Chen, C.; Ansari, S.; Zadeh, H.H.; Snead, M.L.; Shi, S. Application of stem cells derived from the periodontal ligament or gingival tissue sources for tendon tissue regeneration. Biomaterials 2014, 35, 2642-2650. [CrossRef] [PubMed]

107. Wang, F.; Yu, M.; Yan, X.; Wen, Y.; Zeng, Q.; Yue, W.; Yang, P.; Pei, X. Gingiva-derived mesenchymal stem cell-mediated therapeutic approach for bone tissue regeneration. Stem Cells Dev. 2011, 20, 2093-2102. [CrossRef]

108. Kawashima, N. Characterisation of dental pulp stem cells: A new horizon for tissue regeneration? Arch. Oral Biol. 2012, 57, 1439-1458. [CrossRef]

109. Karaöz, E.; Doğan, B.N.; Aksoy, A.; Gacar, G.; Akyüz, S.; Ayhan, S.; Genç, Z.S.; Yürüker, S.; Duruksu, G.; Demircan, P.C.; et al. Isolation and in vitro characterisation of dental pulp stem cells from natal teeth. Histochem. Cell Biol. 2010, 133, 95-112. [CrossRef] 
110. Gronthos, S.; Brahim, J.; Li, W.; Fisher, L.W.; Cherman, N.; Boyde, A.; DenBesten, P.; Robey, P.G.; Shi, S. Stem cell properties of human dental pulp stem cells. J. Dent. Res. 2002, 81, 531-535. [CrossRef]

111. Yamada, Y.; Fujimoto, A.; Ito, A.; Yoshimi, R.; Ueda, M. Cluster analysis and gene expression profiles: A cDNA microarray system-based comparison between human dental pulp stem cells (hDPSCs) and human mesenchymal stem cells (hMSCs) for tissue engineering cell therapy. Biomaterials 2006, 27, 3766-3781. [CrossRef] [PubMed]

112. Patel, M.; Smith, A.J.; Sloan, A.J.; Smith, G.; Cooper, P.R. Phenotype and behaviour of dental pulp cells during expansion culture. Arch. Oral Biol. 2009, 54, 898-908. [CrossRef] [PubMed]

113. Bakopoulou, A.; Apatzidou, D.; Aggelidou, E.; Gousopoulou, E.; Leyhausen, G.; Volk, J.; Kritis, A.; Koidis, P.; Geurtsen, W. Isolation and prolonged expansion of oral mesenchymal stem cells under clinical-grade, GMP-compliant conditions differentially affects "stemness" properties. Stem Cell Res. Ther. 2017, 8, 247. [CrossRef]

114. Spath, L.; Rotilio, V.; Alessandrini, M.; Gambara, G.; De Angelis, L.; Mancini, M.; Mitsiadis, T.A.; Vivarelli, E.; Naro, F.; Filippini, A.; et al. Explant-derived human dental pulp stem cells enhance differentiation and proliferation potentials. J. Cell Mol. Med. 2010, 14, 1635-1644. [CrossRef] [PubMed]

115. Feng, X.; Xing, J.; Feng, G.; Sang, A.; Shen, B.; Xu, Y.; Jiang, J.; Liu, S.; Tan, W.; Gu, Z.; et al. Age-dependent impaired neurogenic differentiation capacity of dental stem cell is associated with Wnt/ $\beta$-catenin signaling. Cell Mol. Neurobiol. 2013, 33, 1023-1031. [CrossRef]

116. Sakai, K.; Yamamoto, A.; Matsubara, K.; Nakamura, S.; Naruse, M.; Yamagata, M.; Sakamoto, K.; Tauchi, R.; Wakao, N.; Imagama, S.; et al. Human dental pulp-derived stem cells promote locomotor recovery after complete transection of the rat spinal cord by multiple neuro-regenerative mechanisms. J. Clin. Investig. 2012, 122, 80-90. [CrossRef]

117. Király, M.; Porcsalmy, B.; Pataki, A.; Kádár, K.; Jelitai, M.; Molnár, B.; Hermann, P.; Gera, I.; Grimm, W.-D.; Ganss, B.; et al. Simultaneous PKC and cAMP activation induces differentiation of human dental pulp stem cells into functionally active neurons. Neurochem. Int. 2009, 55, 323-332. [CrossRef]

118. Vishwanath, V.R.; Nadig, R.R.; Nadig, R.; Prasanna, J.S.; Karthik, J.; Pai, V.S. Differentiation of isolated and characterized human dental pulp stem cells and stem cells from human exfoliated deciduous teeth: An in vitro study. J. Conserv. Dent. 2013, 16, 423-428. [CrossRef]

119. Kaukua, N.; Chen, M.; Guarnieri, P.; Dahl, M.; Lim, M.L.; Yucel-Lindberg, T.; Sundström, E.; Adameyko, I.; Mao, J.J.; Fried, K. Molecular differences between stromal cell populations from deciduous and permanent human teeth. Stem Cell Res. Ther. 2015, 6, 59. [CrossRef]

120. Akpinar, G.; Kasap, M.; Aksoy, A.; Duruksu, G.; Gacar, G.; Karaoz, E. Phenotypic and proteomic characteristics of human dental pulp derived mesenchymal stem cells from a natal, an exfoliated deciduous, and an impacted third molar tooth. Stem Cells Int. 2014, 2014, 457059. [CrossRef] [PubMed]

121. Tziafas, D.; Kodonas, K. Differentiation potential of dental papilla, dental pulp, and apical papilla progenitor cells. J. Endod. 2010, 36, 781-789. [CrossRef]

122. Liu, Q.; Cen, L.; Yin, S.; Chen, L.; Liu, G.; Chang, J.; Cui, L. A comparative study of proliferation and osteogenic differentiation of adipose-derived stem cells on akermanite and $\beta$-TCP ceramics. Biomaterials 2008, 29, 4792-4799. [CrossRef] [PubMed]

123. Jiang, X.; Zhao, J.; Wang, S.; Sun, X.; Zhang, X.; Chen, J.; Kaplan, D.L.; Zhang, Z. Mandibular repair in rats with premineralized silk scaffolds and BMP-2-modified bMSCs. Biomaterials 2009, 30, 4522-4532. [CrossRef]

124. Lee, J.-S.; Lee, J.-M.; Im, G.-I. Electroporation-mediated transfer of Runx2 and Osterix genes to enhance osteogenesis of adipose stem cells. Biomaterials 2011, 32, 760-768. [CrossRef]

125. Yu, J.; He, H.; Tang, C.; Zhang, G.; Li, Y.; Wang, R.; Shi, J.; Jin, Y. Differentiation potential of STRO-1+ dental pulp stem cells changes during cell passaging. BMC Cell Biol. 2010, 11, 32. [CrossRef]

126. Luo, Z.; Kohli, M.R.; Yu, Q.; Kim, S.; Qu, T.; He, W. Biodentine induces human dental pulp stem cell differentiation through mitogen-activated protein kinase and calcium-/calmodulin-dependent protein kinase II pathways. J. Endod. 2014, 40, 937-942. [CrossRef]

127. Miyashita, S.; Ahmed, N.E.M.B.; Murakami, M.; Iohara, K.; Yamamoto, T.; Horibe, H.; Kurita, K.; Takano-Yamamoto, T.; Nakashima, M. Mechanical forces induce odontoblastic differentiation of mesenchymal stem cells on three-dimensional biomimetic scaffolds. J. Tissue Eng. Regen. Med. 2017, 11, 434-446. [CrossRef] [PubMed]

128. Choi, Y.-A.; Seol, M.-Y.; Shin, H.-I.; Park, E.K. Bobby sox homology regulates odontoblast differentiation of human dental pulp stem cells/progenitors. Cell Commun. Signal 2014, 12, 35. [CrossRef] [PubMed]

129. Shen, W.-C.; Lai, Y.-C.; Li, L.-H.; Liao, K.; Lai, H.-C.; Kao, S.-Y.; Wang, J.; Chuong, C.-M.; Hung, S.-C. Methylation and PTEN activation in dental pulp mesenchymal stem cells promotes osteogenesis and reduces oncogenesis. Nat. Commun. 2019, 10, 2226. [CrossRef]

130. Raoof, M.; Yaghoobi, M.M.; Derakhshani, A.; Kamal-abadi, A.M.; Ebrahimi, B.; Abbasnejad, M.; Shokouhinejad, N. A modified efficient method for dental pulp stem cell isolation. Dent. Res. J. 2014, 11, 244-250.

131. Naz, S.; Khan, F.R.; Zohra, R.R.; Lakhundi, S.S.; Khan, M.S.; Mohammed, N.; Ahmad, T. Isolation and culture of dental pulp stem cells from permanent and deciduous teeth. Pak. J. Med. Sci. 2019, 35, 997-1002. [CrossRef] [PubMed]

132. Lindemann, D.; Werle, S.B.; Steffens, D.; Garcia-Godoy, F.; Pranke, P.; Casagrande, L. Effects of cryopreservation on the characteristics of dental pulp stem cells of intact deciduous teeth. Arch. Oral Biol. 2014, 59, 970-976. [CrossRef] 
133. Lin, S.-L.; Chang, W.-J.; Lin, C.-Y.; Hsieh, S.-C.; Lee, S.-Y.; Fan, K.-H.; Lin, C.-T.; Huang, H.-M. Static magnetic field increases survival rate of dental pulp stem cells during DMSO-free cryopreservation. Electromagn. Biol. Med. 2015, 34, 302-308. [CrossRef]

134. Gioventù, S.; Andriolo, G.; Bonino, F.; Frasca, S.; Lazzari, L.; Montelatici, E.; Santoro, F.; Rebulla, P. A novel method for banking dental pulp stem cells. Transfus. Apher. Sci. 2012, 47, 199-206. [CrossRef]

135. Mabuchi, Y.; Morikawa, S.; Harada, S.; Niibe, K.; Suzuki, S.; Renault-Mihara, F.; Houlihan, D.D.; Akazawa, C.; Okano, H.; Matsuzaki, Y. LNGFR+THY-1+VCAM-1hi+ cells reveal functionally distinct subpopulations in mesenchymal stem cells. Stem Cell Rep. 2013, 1, 152-165. [CrossRef]

136. Bühring, H.-J.; Battula, V.L.; Treml, S.; Schewe, B.; Kanz, L.; Vogel, W. Novel markers for the prospective isolation of human MSC. Ann. N. Y. Acad. Sci. 2007, 1106, 262-271. [CrossRef]

137. Yasui, T.; Mabuchi, Y.; Toriumi, H.; Ebine, T.; Niibe, K.; Houlihan, D.D.; Morikawa, S.; Onizawa, K.; Kawana, H.; Akazawa, C.; et al. Purified human dental pulp stem cells promote osteogenic regeneration. J. Dent. Res. 2016, 95, 206-214. [CrossRef]

138. Baghaban Eslaminejad, M.; Malakooty Poor, E. Mesenchymal stem cells as a potent cell source for articular cartilage regeneration. World J. Stem Cells 2014, 6, 344-354. [CrossRef] [PubMed]

139. Allen, K.D.; Athanasiou, K.A. Tissue engineering of the TMJ disc: A review. Tissue Eng. 2006, 12, 1183-1196. [CrossRef] [PubMed]

140. Khajeh, S.; Razban, V.; Talaei-Khozani, T.; Soleimani, M.; Asadi-Golshan, R.; Dehghani, F.; Ramezani, A.; Mostafavi-Pour, Z. Enhanced chondrogenic differentiation of dental pulp-derived mesenchymal stem cells in 3D pellet culture system: Effect of mimicking hypoxia. Biologia 2018, 73, 715-726. [CrossRef]

141. Chen, Y.; Zhao, Q.; Yang, X.; Yu, X.; Yu, D.; Zhao, W. Effects of cobalt chloride on the stem cell marker expression and osteogenic differentiation of stem cells from human exfoliated deciduous teeth. Cell Stress Chaperones 2019, 24, 527-538. [CrossRef]

142. Laksana, K.; Sooampon, S.; Pavasant, P.; Sriarj, W. Cobalt chloride enhances the stemness of human dental pulp cells. J. Endod. 2017, 43, 760-765. [CrossRef] [PubMed]

143. Ejtehadifar, M.; Shamsasenjan, K.; Movassaghpour, A.; Akbarzadehlaleh, P.; Dehdilani, N.; Abbasi, P.; Molaeipour, Z.; Saleh, M. The effect of hypoxia on mesenchymal stem cell biology. Adv. Pharm. Bull. 2015, 5, 141-149. [CrossRef] [PubMed]

144. Haque, N.; Rahman, M.T.; Abu Kasim, N.H.; Alabsi, A.M. Hypoxic culture conditions as a solution for mesenchymal stem cell based regenerative therapy. Sci. World J. 2013, 2013, e632972. [CrossRef]

145. Jahangir, S.; Eglin, D.; Pötter, N.; Khozaei Ravari, M.; Stoddart, M.J.; Samadikuchaksaraei, A.; Alini, M.; Baghaban Eslaminejad, M.; Safa, M. Inhibition of hypertrophy and improving chondrocyte differentiation by MMP-13 inhibitor small molecule encapsulated in alginate-chondroitin sulfate-platelet lysate hydrogel. Stem Cell Res. Ther. 2020, 11, 436. [CrossRef] [PubMed]

146. Chen, S.; Fu, P.; Cong, R.; Wu, H.; Pei, M. Strategies to minimize hypertrophy in cartilage engineering and regeneration. Genes Dis. 2015, 2, 76-95. [CrossRef]

147. Mueller, M.B.; Fischer, M.; Zellner, J.; Berner, A.; Dienstknecht, T.; Kujat, R.; Prantl, L.; Nerlich, M.; Tuan, R.S.; Angele, P. Effect of parathyroid hormone-related protein in an in vitro hypertrophy model for mesenchymal stem cell chondrogenesis. Int. Orthop. 2013, 37, 945-951. [CrossRef]

148. Bertram, H.; Boeuf, S.; Wachters, J.; Boehmer, S.; Heisel, C.; Hofmann, M.W.; Piecha, D.; Richter, W. Matrix metalloprotease inhibitors suppress initiation and progression of chondrogenic differentiation of mesenchymal stromal cells in vitro. Stem Cells Dev. 2009, 18, 881-892. [CrossRef] [PubMed]

149. Shintani, N.; Siebenrock, K.A.; Hunziker, E.B. TGF-B1 enhances the BMP-2-Induced chondrogenesis of bovine synovial explants and arrests downstream differentiation at an early stage of hypertrophy. PLoS ONE 2013, 8, e53086. [CrossRef]

150. Pei, M.; Chen, D.; Li, J.; Wei, L. Histone deacetylase 4 promotes TGF-beta1-induced synovium-derived stem cell chondrogenesis but inhibits chondrogenically differentiated stem cell hypertrophy. Differentiation 2009, 78, 260-268. [CrossRef] [PubMed]

151. Lengner, C.J.; Hassan, M.Q.; Serra, R.W.; Lepper, C.; van Wijnen, A.J.; Stein, J.L.; Lian, J.B.; Stein, G.S. Nkx3.2-mediated repression of Runx2 promotes chondrogenic differentiation. J. Biol. Chem. 2005, 280, 15872-15879. [CrossRef]

152. Hirao, M.; Tamai, N.; Tsumaki, N.; Yoshikawa, H.; Myoui, A. Oxygen tension regulates chondrocyte differentiation and function during endochondral ossification. J. Biol. Chem. 2006, 281, 31079-31092. [CrossRef]

153. Lee, H.-H.; Chang, C.-C.; Shieh, M.-J.; Wang, J.-P.; Chen, Y.-T.; Young, T.-H.; Hung, S.-C. Hypoxia enhances chondrogenesis and prevents terminal differentiation through PI3K/Akt/FoxO dependent anti-apoptotic effect. Sci. Rep. 2013, 3, 2683. [CrossRef] [PubMed]

154. Hsu, S.; Huang, G.-S.; Lin, S.Y.F.; Feng, F.; Ho, T.-T.; Liao, Y.-C. Enhanced chondrogenic differentiation potential of human gingival fibroblasts by spheroid formation on chitosan membranes. Tissue Eng. Part A 2012, 18, 67-79. [CrossRef]

155. Ferré, F.C.; Larjava, H.; Loison-Robert, L.-S.; Berbar, T.; Owen, G.R.; Berdal, A.; Chérifi, H.; Gogly, B.; Häkkinen, L.; Fournier, B.P.J. Formation of cartilage and synovial tissue by human gingival stem cells. Stem Cells Dev. 2014, 23, 2895-2907. [CrossRef]

156. Lefebvre, V.; Dvir-Ginzberg, M. SOX9 and the many facets of its regulation in the chondrocyte lineage. Connect. Tissue Res. 2017, 58, 2-14. [CrossRef]

157. Jo, A.; Denduluri, S.; Zhang, B.; Wang, Z.; Yin, L.; Yan, Z.; Kang, R.; Shi, L.L.; Mok, J.; Lee, M.J.; et al. The versatile functions of Sox9 in development, stem cells, and human diseases. Genes Dis. 2014, 1, 149-161. [CrossRef] [PubMed]

158. Zhang, X.; Wu, S.; Naccarato, T.; Prakash-Damani, M.; Chou, Y.; Chu, C.-Q.; Zhu, Y. Regeneration of hyaline-like cartilage in situ with SOX9 stimulation of bone marrow-derived mesenchymal stem cells. PLoS ONE 2017, 12, e0180138. [CrossRef]

159. Jiang, X.; Huang, X.; Jiang, T.; Zheng, L.; Zhao, J.; Zhang, X. The role of Sox9 in collagen hydrogel-mediated chondrogenic differentiation of adult mesenchymal stem cells (MSCs). Biomater. Sci. 2018, 6, 1556-1568. [CrossRef] 
160. Akiyama, H. Control of chondrogenesis by the transcription factor Sox9. Mod. Rheumatol. 2008, 18, 213-219. [CrossRef] [PubMed]

161. Ng, L.-J.; Wheatley, S.; Muscat, G.E.O.; Conway-Campbell, J.; Bowles, J.; Wright, E.; Bell, D.M.; Tam, P.P.L.; Cheah, K.S.E.; Koopman, P. SOX9 binds DNA, activates transcription, and coexpresses with type II collagen during chondrogenesis in the mouse. Dev. Biol. 1997, 183, 108-121. [CrossRef]

162. Hardingham, T.E.; Oldershaw, R.A.; Tew, S.R. Cartilage, SOX9 and notch signals in chondrogenesis. J. Anat. 2006, 209, 469-480. [CrossRef] [PubMed]

163. Oldershaw, R.A.; Hardingham, T.E. Notch signaling during chondrogenesis of human bone marrow stem cells. Bone 2010, 46, 286-293. [CrossRef]

164. Karlsson, C.; Lindahl, A. Notch signaling in chondrogenesis. Int. Rev. Cell Mol. Biol. 2009, 275, 65-88. [CrossRef]

165. Mead, T.J.; Yutzey, K.E. Notch pathway regulation of chondrocyte differentiation and proliferation during appendicular and axial skeleton development. Proc. Natl. Acad. Sci. USA 2009, 106, 14420-14425. [CrossRef] [PubMed]

166. Sassi, N.; Laadhar, L.; Driss, M.; Kallel-Sellami, M.; Sellami, S.; Makni, S. The role of the Notch pathway in healthy and osteoarthritic articular cartilage: From experimental models to ex vivo studies. Arthritis Res. Ther. 2011, 13, 208. [CrossRef]

167. Green, J.D.; Tollemar, V.; Dougherty, M.; Yan, Z.; Yin, L.; Ye, J.; Collier, Z.; Mohammed, M.K.; Haydon, R.C.; Luu, H.H.; et al. Multifaceted signaling regulators of chondrogenesis: Implications in cartilage regeneration and tissue engineering. Genes Dis. 2015, 2, 307-327. [CrossRef]

168. Yi, S.W.; Kim, H.J.; Oh, H.J.; Shin, H.; Lee, J.S.; Park, J.S.; Park, K.-H. Gene expression profiling of chondrogenic differentiation by dexamethasone-conjugated polyethyleneimine with SOX trio genes in stem cells. Stem Cell Res. Ther. 2018, 9, 341. [CrossRef] [PubMed]

169. Almalki, S.G.; Agrawal, D.K. Key transcription factors in the differentiation of mesenchymal stem cells. Differentiation 2016, 92, 41-51. [CrossRef]

170. Fernandes, T.L.; Shimomura, K.; Asperti, A.; Pinheiro, C.C.G.; Caetano, H.V.A.; Oliveira, C.R.G.C.M.; Nakamura, N.; Hernandez, A.J.; Bueno, D.F. Development of a novel large animal model to evaluate human dental pulp stem cells for articular cartilage treatment. Stem Cell Rev. Rep. 2018, 14, 734-743. [CrossRef] [PubMed]

171. Westin, C.B.; Trinca, R.B.; Zuliani, C.; Coimbra, I.B.; Moraes, Â.M. Differentiation of dental pulp stem cells into chondrocytes upon culture on porous chitosan-xanthan scaffolds in the presence of kartogenin. Mater. Sci. Eng. C Mater. Biol. Appl. 2017, 80, 594-602. [CrossRef] [PubMed]

172. Mata, M.; Milian, L.; Oliver, M.; Zurriaga, J.; Sancho-Tello, M.; de Llano, J.J.M.; Carda, C. In vivo articular cartilage regeneration using human dental pulp stem cells cultured in an alginate scaffold: A preliminary study. Stem Cells Int. 2017, 2017 , e8309256. [CrossRef] [PubMed]

173. Ishikawa, J.; Takahashi, N.; Matsumoto, T.; Yoshioka, Y.; Yamamoto, N.; Nishikawa, M.; Hibi, H.; Ishigro, N.; Ueda, M.; Furukawa, K.; et al. Factors secreted from dental pulp stem cells show multifaceted benefits for treating experimental rheumatoid arthritis. Bone 2016, 83, 210-219. [CrossRef]

174. Chen, K.; Xiong, H.; Xu, N.; Shen, Y.; Huang, Y.; Liu, C. Chondrogenic potential of stem cells from human exfoliated deciduous teeth in vitro and in vivo. Acta Odontol. Scand. 2014, 72, 664-672. [CrossRef] [PubMed]

175. Rizk, A.; Rabie, A.B.M. Human dental pulp stem cells expressing transforming growth factor $\beta 3$ transgene for cartilage-like tissue engineering. Cytotherapy 2013, 15, 712-725. [CrossRef] [PubMed]

176. Hilkens, P.; Gervois, P.; Fanton, Y.; Vanormelingen, J.; Martens, W.; Struys, T.; Politis, C.; Lambrichts, I.; Bronckaers, A. Effect of isolation methodology on stem cell properties and multilineage differentiation potential of human dental pulp stem cells. Cell Tissue Res. 2013, 353, 65-78. [CrossRef]

177. Dai, J.; Wang, J.; Lu, J.; Zou, D.; Sun, H.; Dong, Y.; Yu, H.; Zhang, L.; Yang, T.; Zhang, X.; et al. The effect of co-culturing costal chondrocytes and dental pulp stem cells combined with exogenous FGF9 protein on chondrogenesis and ossification in engineered cartilage. Biomaterials 2012, 33, 7699-7711. [CrossRef] [PubMed]

178. Xu, Y.; Chen, C.; Hellwarth, P.B.; Bao, X. Biomaterials for stem cell engineering and biomanufacturing. Bioact. Mater. 2019, 4, 366-379. [CrossRef]

179. Willerth, S.M.; Sakiyama-Elbert, S.E. Combining stem cells and biomaterial scaffolds for constructing tissues and cell delivery. StemJournal 2019, 1, 1-25. [CrossRef]

180. Dzobo, K.; Thomford, N.E.; Senthebane, D.A.; Shipanga, H.; Rowe, A.; Dandara, C.; Pillay, M.; Motaung, K.S.C.M. Advances in regenerative medicine and tissue engineering: Innovation and transformation of medicine. Stem Cells Int. 2018, 2018, e2495848. [CrossRef]

181. Loh, C.-Y.; Chai, J.Y.; Tang, T.F.; Wong, W.F.; Sethi, G.; Shanmugam, M.K.; Chong, P.P.; Looi, C.Y. The E-Cadherin and N-Cadherin switch in epithelial-to-mesenchymal transition: Signaling, therapeutic implications, and challenges. Cells 2019, 8, 1118. [CrossRef]

182. Tuli, R.; Tuli, S.; Nandi, S.; Huang, X.; Manner, P.A.; Hozack, W.J.; Danielson, K.G.; Hall, D.J.; Tuan, R.S. Transforming growth factor-beta-mediated chondrogenesis of human mesenchymal progenitor cells involves N-cadherin and mitogen-activated protein kinase and Wnt signaling cross-talk. J. Biol. Chem. 2003, 278, 41227-41236. [CrossRef] [PubMed]

183. Tang, Q.O.; Shakib, K.; Heliotis, M.; Tsiridis, E.; Mantalaris, A.; Ripamonti, U.; Tsiridis, E. TGF-beta3: A potential biological therapy for enhancing chondrogenesis. Expert Opin. Biol. Ther. 2009, 9, 689-701. [CrossRef] [PubMed]

184. Wu, M.; Chen, G.; Li, Y.-P. TGF- $\beta$ and BMP signaling in osteoblast, skeletal development, and bone formation, homeostasis and disease. Bone Res. 2016, 4, 16009. [CrossRef] [PubMed] 
185. Guo, X.; Wang, X.-F. Signaling cross-talk between TGF- $\beta$ /BMP and other pathways. Cell Res. 2009, 19, 71-88. [CrossRef]

186. Keller, B.; Yang, T.; Chen, Y.; Munivez, E.; Bertin, T.; Zabel, B.; Lee, B. Interaction of TGF $\beta$ and BMP signaling pathways during chondrogenesis. PLoS ONE 2011, 6, e16421. [CrossRef] [PubMed]

187. Thielen, N.G.M.; van der Kraan, P.M.; van Caam, A.P.M. TGF $\beta$ /BMP signaling pathway in cartilage homeostasis. Cells 2019, 8, 969. [CrossRef] [PubMed]

188. Zhang, M.; Zhou, Q.; Liang, Q.-Q.; Li, C.-G.; Holz, J.D.; Tang, D.; Sheu, T.-J.; Li, T.-F.; Shi, Q.; Wang, Y.-J. IGF-1 regulation of type II collagen and MMP-13 expression in rat endplate chondrocytes via distinct signaling pathways. Osteoarthr. Cartil. 2009, 17, 100-106. [CrossRef]

189. Li, Y.; Wang, Y.; Chubinskaya, S.; Schoeberl, B.; Florine, E.; Kopesky, P.; Grodzinsky, A.J. Effects of insulin-like growth factor-1 and dexamethasone on cytokine-challenged cartilage: Relevance to post traumatic osteoarthritis. Osteoarthr. Cartil. 2015, 23, 266-274. [CrossRef]

190. Fortier, L.A.; Barker, J.U.; Strauss, E.J.; McCarrel, T.M.; Cole, B.J. The role of growth factors in cartilage repair. Clin. Orthop. Relat. Res. 2011, 469, 2706-2715. [CrossRef]

191. Zhang, Z.; Li, L.; Yang, W.; Cao, Y.; Shi, Y.; Li, X.; Zhang, Q. The effects of different doses of IGF-1 on cartilage and subchondral bone during the repair of full-thickness articular cartilage defects in rabbits. Osteoarthr. Cartil. 2017, 25, 309-320. [CrossRef]

192. Chen, C.-Y.; Li, C.; Ke, C.-J.; Sun, J.-S.; Lin, F.-H. Kartogenin enhances chondrogenic differentiation of MSCs in 3D Tri-copolymer scaffolds and the self-designed bioreactor system. Biomolecules 2021, 11, 115. [CrossRef]

193. Liu, F.; Xu, H.; Huang, H. A novel kartogenin-platelet-rich plasma gel enhances chondrogenesis of bone marrow mesenchymal stem cells in vitro and promotes wounded meniscus healing in vivo. Stem Cell Res. Ther. 2019, 10, 201. [CrossRef]

194. Huang, H.; Xu, H.; Zhao, J. A novel approach for meniscal regeneration using kartogenin-treated autologous tendon graft. Am. J. Sports Med. 2017, 45, 3289-3297. [CrossRef]

195. Kwon, J.Y.; Lee, S.H.; Na, H.-S.; Jung, K.; Choi, J.; Cho, K.H.; Lee, C.-Y.; Kim, S.J.; Park, S.-H.; Shin, D.-Y.; et al. Kartogenin inhibits pain behavior, chondrocyte inflammation, and attenuates osteoarthritis progression in mice through induction of IL-10. Sci. Rep. 2018, 8, 13832. [CrossRef]

196. Leung, B.P.; Sattar, N.; Crilly, A.; Prach, M.; McCarey, D.W.; Payne, H.; Madhok, R.; Campbell, C.; Gracie, J.A.; Liew, F.Y.; et al. A novel anti-inflammatory role for simvastatin in inflammatory arthritis. J. Immunol. 2003, 170, 1524-1530. [CrossRef]

197. Conaghan, P.G. The effects of statins on osteoarthritis structural progression: Another glimpse of the Holy Grail? Ann. Rheum. Dis. 2012, 71, 633-634. [CrossRef] [PubMed]

198. Nikolova, M.P.; Chavali, M.S. Recent advances in biomaterials for 3D scaffolds: A review. Bioact. Mater. 2019, 4, 271. [CrossRef]

199. Loh, Q.L.; Choong, C. Three-dimensional scaffolds for tissue engineering applications: Role of porosity and pore size. Tissue Eng. Part B Rev. 2013, 19, 485-502. [CrossRef]

200. Yin, Z.; Yang, X.; Jiang, Y.; Xing, L.; Xu, Y.; Lu, Y.; Ding, P.; Ma, J.; Xu, Y.; Gui, J. Platelet-rich plasma combined with agarose as a bioactive scaffold to enhance cartilage repair: An in vitro study. J. Biomater. Appl. 2014, 28, 1039-1050. [CrossRef] [PubMed]

201. Hubka, K.M.; Dahlin, R.L.; Meretoja, V.V.; Kasper, F.K.; Mikos, A.G. Enhancing chondrogenic phenotype for cartilage tissue engineering: Monoculture and coculture of articular chondrocytes and mesenchymal stem cells. Tissue Eng. Part B Rev. 2014, 20, 641-654. [CrossRef]

202. Li, J.; Chen, G.; Xu, X.; Abdou, P.; Jiang, Q.; Shi, D.; Gu, Z. Advances of injectable hydrogel-based scaffolds for cartilage regeneration. Regen. Biomater. 2019, 6, 129-140. [CrossRef] [PubMed]

203. Iwasa, J.; Engebretsen, L.; Shima, Y.; Ochi, M. Clinical application of scaffolds for cartilage tissue engineering. Knee Surg Sports Traumatol. Arthrosc. 2009, 17, 561-577. [CrossRef] [PubMed]

204. Dashtdar, H.; Murali, M.R.; Selvaratnam, L.; Balaji Raghavendran, H.; Suhaeb, A.M.; Ahmad, T.S.; Kamarul, T. Ultra-structural changes and expression of chondrogenic and hypertrophic genes during chondrogenic differentiation of mesenchymal stromal cells in alginate beads. Peer 2016,4 . [CrossRef] [PubMed]

205. Mohan, N.; Mohanan, P.; Sabareeswaran, A.; Nair, P. Chitosan-hyaluronic acid hydrogel for cartilage repair. Int. J. Biol. Macromol. 2017, 104, 1936-1945. [CrossRef]

206. Nagura, I.; Fujioka, H.; Kokubu, T.; Makino, T.; Sumi, Y.; Kurosaka, M. Repair of osteochondral defects with a new porous synthetic polymer scaffold. J. Bone Jt. Surgery. Br. Vol. 2007, 89, 258-264. [CrossRef]

207. Warnock, J.J.; Baker, L.; Ballard, G.A.; Ott, J. In vitro synthesis of tensioned synoviocyte bioscaffolds for meniscal fibrocartilage tissue engineering. BMC Vet. Res. 2013, 9, 242. [CrossRef]

208. Johnson, K.A.; Rose, D.M.; Terkeltaub, R.A. Factor XIIIA mobilizes transglutaminase 2 to induce chondrocyte hypertrophic differentiation. J. Cell Sci. 2008, 121, 2256-2264. [CrossRef]

209. Adamczyk, M. Transglutaminase 2 in cartilage homoeostasis: Novel links with inflammatory osteoarthritis. Amino Acids 2017, 49, 625-633. [CrossRef]

210. Li, J.; Dong, S. The signaling pathways involved in chondrocyte differentiation and hypertrophic differentiation. Stem Cells Int. 2016, 2016, e2470351. [CrossRef] [PubMed]

211. Soltani, M.; Malek, R.A.; Elmarzugi, N.A.; Mahomoodally, M.F.; Uy, D.; Leng, O.M.; El-Enshasy, H.A. Cordycepin: A biotherapeutic molecule from medicinal mushroom. Biol. Macrofungi 2019, 319-349. [CrossRef] 
212. Cao, Z.; Dou, C.; Li, J.; Tang, X.; Xiang, J.; Zhao, C.; Zhu, L.; Bai, Y.; Xiang, Q.; Dong, S. Cordycepin inhibits chondrocyte hypertrophy of mesenchymal stem cells through PI3K/Bapx1 and Notch signaling pathway. BMB Rep. 2016, 49, 548-553. [CrossRef] [PubMed]

213. Jacek, P.; Szustak, M.; Kubiak, K.; Gendaszewska-Darmach, E.; Ludwicka, K.; Bielecki, S. Scaffolds for chondrogenic cells cultivation prepared from bacterial cellulose with relaxed fibers structure induced genetically. Nanomaterials 2018, 8, 66. [CrossRef]

214. Kreuz, P.C.; Gentili, C.; Samans, B.; Martinelli, D.; Krüger, J.P.; Mittelmeier, W.; Endres, M.; Cancedda, R.; Kaps, C. Scaffoldassisted cartilage tissue engineering using infant chondrocytes from human hip cartilage. Osteoarthr. Cartil. 2013, 21, 1997-2005. [CrossRef]

215. Ollitrault, D.; Legendre, F.; Drougard, C.; Briand, M.; Benateau, H.; Goux, D.; Chajra, H.; Poulain, L.; Hartmann, D.; Vivien, D.; et al. BMP-2, hypoxia, and COL1A1/HtrA1 siRNAs favor neo-cartilage hyaline matrix formation in chondrocytes. Tissue Eng. Part C Methods 2015, 21, 133-147. [CrossRef]

216. Dental Stem Cell Banking I Wisdom Teeth, Stem Cell Storage I Tooth Bank. Available online: https://www.toothbank.com/ (accessed on 6 April 2021).

217. Mothercell. Available online: https:/ /www.mothercell.com/ (accessed on 6 April 2021).

218. Milk Tooth Cell Banking and Baby Tooth Storage I BioEden. Available online: https://www.bioeden.com/uk/ (accessed on 6 April 2021).

219. Stemade. Available online: http://stemade.com/discover_happiness/ (accessed on 6 April 2021).

220. Gandia, C.; Armiñan, A.; García-Verdugo, J.M.; Lledó, E.; Ruiz, A.; Miñana, M.D.; Sanchez-Torrijos, J.; Payá, R.; Mirabet, V.; Carbonell-Uberos, F; i et al. Human dental pulp stem cells improve left ventricular function, induce angiogenesis, and reduce infarct size in rats with acute myocardial infarction. Stem Cells 2008, 26, 638-645. [CrossRef]

221. Nosrat, I.V.; Widenfalk, J.; Olson, L.; Nosrat, C.A. Dental pulp cells produce neurotrophic factors, interact with trigeminal neurons in vitro, and rescue motoneurons after spinal cord injury. Dev. Biol. 2001, 238, 120-132. [CrossRef]

222. Kerkis, I.; Ambrosio, C.E.; Kerkis, A.; Martins, D.S.; Zucconi, E.; Fonseca, S.A.S.; Cabral, R.M.; Maranduba, C.M.C.; Gaiad, T.P.; Morini, A.C.; et al. Early transplantation of human immature dental pulp stem cells from baby teeth to golden retriever muscular dystrophy (GRMD) dogs: Local or systemic? J. Transl. Med. 2008, 6, 35. [CrossRef]

223. Graziano, A.; d'Aquino, R.; Laino, G.; Papaccio, G. Dental pulp stem cells: A promising tool for bone regeneration. Stem Cell Rev. 2008, 4, 21-26. [CrossRef] 